\title{
Decoupling and essential effects of lean management on job satisfaction, health and depression. A mixed methods approach. ${ }^{1}$
}

\author{
Gregor Bouville \\ Université Paris-Dauphine, PSL Research University \\ CNRS, UMR [7088], DRM, [Management et Organisation] \\ 75016 PARIS, France. \\ Céline Schmidt \\ Université de Rennes 1, Centre d'Economie et de Management \\ CREM, UMR - CNRS 6211. \\ 35000 RENNES, France.
}

\begin{abstract}
The literature has analyzed the effects of lean management on job satisfaction and health in terms of decoupling or essential effects. However, these studies give a partial understanding of the phenomenon considering these two effects separately, and do not yet explain how and which lean characteristics influence employees' job satisfaction or health. The purpose of this article is to study these two competing claims. We used a mixed methods strategy to contribute to this stream of research combining both qualitative (a case study) and quantitative (statistical analysis based on the 2016-2017 national French SUMER survey on 26,494 employees) studies. We showed that employees' job satisfaction and health result from both lean decoupling and essential effects. We contributed to lean literature in clarifying the theoretical definition of lean management considered as a bundle, which involved identifying a distinctive coherent combination of lean characteristics in terms organizational principles, work organization and management tools built around rationalization logic. The first empirical contribution was to shed light on the way lean decoupling could be associated with employees' job dissatisfaction and health problems. Our second contribution was to identify a negative essential effect of a lean bundle on work health and general health through work intensification. Moreover, we found that the core lean just-in-time principle and both core work organization characteristics - work standardization and quality management - are associated with health and depression problems.
\end{abstract}

Key words: lean production, lean management, lean bundle, job satisfaction, health, decoupling, well-being, depression, mixed methods.

To cite: Bouville G., Schmidt C. (2019), Decoupling and essential effects of lean management on job satisfaction, health and depression. A mixed methods approach., Revue de Gestion des Ressources Humaines, n¹14, p. 3-30 . DOI : 10.3917/grhu.114.0003.

\footnotetext{
${ }^{1}$ The authors are grateful to the SUMER (Medical Surveillance of Occupational Risks) team for their permission to use the survey data. The survey was jointly sponsored by the DARES (Directorate for the Coordination of Research, Studies and Statistics) and the Directorate of Labor Relations of the French Ministry of Employment, Social Cohesion and Housing. We also would like to thank our reviewers for their insightful comments and suggestions.
} 


\section{Introduction}

Academic research on lean management has increased in the last few years (Hasle, 2014). Yet, it is not clear what employees could expect in terms of job satisfaction and health from this lean expansion. It has been suggested that the organizational model of lean management has contributed towards the recent introduction of several work organization characteristics, which could help improve working conditions (Womack et al., 1990; Hasle, 2014). However, several authors have pointed out the deleterious social and health impacts of lean management on employees (Babson, 1993; Haynes, 1999; Jackson and Mullarkey, 2000; Landsbergis et al., 1999a; Lewchuk and Robertson, 1996; Valeyre et al., 2009). Meanwhile, there is still little understanding on the effects of lean management on job satisfaction and health ${ }^{2}$ and, more precisely, on the process through which lean management impacts them (Hasle, 2014). Moreover, "few contributions discuss the basis of lean or provide a clear definition of the meaning of lean" (Arlbjorn and Freytag, 2013: 174). Previous studies on the job satisfaction and health impact of lean are biased in two ways. First, theorizing lean without considering the gap between theory and practice raises issues. According to the neo-institutional literature, decoupling "means that organizations abide only superficially by institutional pressure and adopt new structures without necessarily implementing the related practices" (Boxenbaum and Jonsson, 2008: 81).

Second, these studies did not identify what the core bundle of lean characteristics is in terms of organizational principles, work organization and management tools. We chose to take into account all the characteristics, considering that each element of the lean system is important. In line with the High-Performance Work System literature, which considers a bundle of HRM

\footnotetext{
${ }^{2}$ In accordance with the World Health Organization (1946: 100), we define health as "a state of complete physical, mental and social well-being and not merely the absence of disease or infirmity." This conception has the advantage of addressing health in both its positive and negative connotations (Althaus et al., 2013).
} 
policies (Guest et al., 2004; MacDuffie, 1995), lean should be considered as a bundle, which involves identifying a distinctive coherent combination of lean characteristics in terms of organizational principles, work organization and management tools built around rationalization logic. This raised a second issue about the essential effects of a lean bundle on employees' outcomes. Previous studies have not considered the essential effects of lean on employees' outcomes, i.e. the effects of a lean bundle in terms of organizational principles, work organization and management tools on employees' job satisfaction and health (i.e., work heath, general health and depression). The present study tries to tackle these two major issues.

This article is structured as follows. First, a literature-based overview on the effects of lean management on employees' job satisfaction and health is addressed. Second, our empirical setting is described, and our data, methods and measures are detailed. We then present successively our three empirical studies. Finally, we discuss our theoretical, methodological and managerial contributions.

\section{Lean management and employees' outcomes: a critical overview}

As claimed by Lewchuk et al. (2001), many authors have asserted the numerous benefits of lean management to employees, but few studies have empirically confirmed these claims. Moreover, while several studies (Anderson-Connolly et al., 2002; Bouville et Alis, 2014; Carter et al., 2013; Jackson and Mullarkey, 2000; Lewchuk et al., 2001 Lewchuk and Robertson, 1996; Parker, 2003; Seppälä and Klemola, 2004; Sprigg and Jackson, 2006; Vidal, 2007; Womack et al., 2009) aim at better understanding the effects of lean work organization characteristics on employees' attitudes or health, unfortunately, the results of these studies are contradictory. We present a literature review of lean and outcomes for employees including studies on human resource management, ergonomic, industrial relations, sociology of work, and work 
psychology. Descriptions of the lean characteristics and effects on health and job satisfaction are listed in Table 1, in addition to an added column that highlights the methodology used.

Table 1 about here

\section{Essential effects and outcomes}

On the one hand, some studies have identified positive effects of lean work organization characteristics (Saurin and Ferreira, 2009; Womack et al., 2009). On the other hand, other studies have pointed out negative consequences of these characteristics associated with lean (Carter et al., 2013; Lewchuck et al., 2001; Lewchuk and Robertson, 1996; Parker, 2003; Sprigg and Jackson, 2006; Vidal, 2007), mixed effects (Bouville and Alis, 2014; Anderson-Connolly et al., 2002; Conti et al., 2006; Cullinane et al., 2014; Seppälä and Klemola, 2004; Schouteten and Benders, 2004) or non significant effects (Jackson and Mullarkey, 2000). Three explanations can be put forward. First, most of the studies mentioned in Table 1 are quantitative, based on questionnaires, surveys or quasi-experimentations. They do not focus on the processes through which work organization characteristics linked to lean management may affect health at work and job satisfaction. Second, most of these studies rest on a sample of blue-collars from one company. The samples of these studies are based on one specific-activity sector (e.g. the automotive components sector in the studies of Lewchuk and Robertson, 1996 and Stewart et al., 2009). These sectoral and contextual contingencies limit the generalization of results.

A third explanation lies in the fact that most of these previous studies use the label "lean" on the studied companies without precisely explaining what work organization characteristics or management tools justify this identification. For example, in Anderson-Connolly et al. (2002), lean is described as a mixture of restructuring, outsourcing, reducing inventory, simplifying production processes and developing cross-functional teams. In this study, the use of the terms "restructuring" and "outsourcing" brings to mind the management concept of "business process 
reengineering" which, while popular in the 1990s, is quite different from lean (Hasle et al., 2012: 841). In another study, Sprigg and Jackson (2006) have described lean management system in call centres in terms of both dialog scripting and performance monitoring.

Table 2 presents the literature review on lean management as a coherent management system based on principles (just-in-time, muda, pull system, production smoothing, elimination of waste, shortening setup time), work organization characteristics (job rotation, teamwork, delegation of responsibilities, problem-solving demand, quality management and standardization) and management tools (Kanban, Kaizen, 5 S, Quality circles, five whys, Andon, Poka-yoke, U-turn layout) in order to rationalize the production of goods or services, from leading researchers (Liker, 2004; Monden, 1983; Ohno, 1988; Womack et al., 1990, 2003). Table 2 confirms the divergence between what is labelled "lean" in the studies presented in Table 1 and the definition of lean management by the forefathers of the concept.

Table 2 about here

\section{Decoupling effects and outcomes}

From this literature review, two types of comments could be drawn to explain these mitigate effects of lean on employees' outcomes. First, problems are caused by the decoupling between lean ideal theory and practices (Bertrand and Stimec, 2011; Womack et al., 2009). Some organizations that implement lean disregard the broader lean philosophy and simply use lean tools to eliminate non-value added activities such as walking that does not seem to increase work content and may be at greater risk of negative health outcomes (Womack et al., 2009). Bertrand and Stimec (2011) have shown that, when lean principles are denatured and only focused on the optimization of the production process, lean deteriorates employees' health. Thus, the main outcome of this stream of research is that the deterioration of employees' job 
satisfaction and health may not originate from lean itself, but from its bad implementation (Landsbergis et al., 1999b).

A second stream of research relies on one main outcome: lean is essentially good (first group of authors: Womack et al., 1990; De Treville and Antonakis, 2006) or bad (second group of authors: Babson, 1993; Berggren, 1992; Parker and Slaughter, 1995) for employees' job satisfaction and health. Among the first group, Womack et al. (1990: 100-102) have considered lean management system as a "creative tension" that makes work "humanly fulfilling". De Treville and Antonakis (2006) have further developed Womack et al.'s (1990) analysis. According to them, if the degree of leanness is just right, lean management implementation will result in an increase in skill variety when employees participate in problem solving, receive training, and - to a lesser extent - rotate jobs. Moreover, if the degree of leanness is just right, lean management implementation is positively related to task identity. Employees can better see how their task contributes to the whole product. Conversely, the second group has argued that "the emancipative potential of lean production is easy to invoke in the abstract, but difficult to specify in concrete terms. Inevitably, efforts to maximize worker rights collide with efforts to maximize return on investment; compromise can mitigate conflict but cannot eliminate the irreducible antagonism between these contending positions" (Babson, 1993: 23). For this second group, lean management creates essentially intensification of work.

We therefore propose two competing research questions:

- What are the essential effects of a bundle of lean organizational principles, work organization characteristics and management tools on employees' job satisfaction and health and how do these effects operate?

- How do the decoupling effects between lean ideal theory and lean practices impact employees' job satisfaction and health?

\section{Methodology: a mixed methods study.}


Mixed methods may be helpful in addressing issues on temporal, network, and institutional embeddedness (Bainbridge and Lee, 2014) as well as on the dynamics of meaning-making (Bartunek and Seo, 2002). In our case, a mixed methods design was used to better understand the complex and intertwined experience of individuals and lean organizations. Mixed methods could also help to clarify the specific effect of lean context, implementation and thinking on job satisfaction and health (Hasle, 2014). We thus integrated the quantitative results from one largescale study on individuals and the qualitative results from a case study of micro-processes and meaning systems. Our research methodology was based on Tashakkori and Teddlie's (2010) and Molina-Azorin's (2012) typologies of mixed methods research designs with four principles: purpose, priority, implementation and design. All indications about research strategy and design implementation were characterized by a system of notation (Morse, 1991). The symbols $(+)$ and arrows $(\rightarrow)$ indicated respectively simultaneous implementation and sequential design. "Capital letters are used to indicate higher priority for a particular method, with lowercase indicating lower priority" (Harrison, 2013: 2155). Bainbridge and Lee (2014) have identified nine combinations using Morse (1991) system and using Tashakkori and Teddlie's (2010) principles (see also Sandelowski's (2003) three design types or Creswell and Plano Clark (2007) five design types). We presented our methodology as a (QUAN + QUAL) in Table 3.

Table 3 about here

Our overarching goal was to advance theoretical and empirical understanding of the role of lean management on employees' job satisfaction and health.

To this end, based on analysis of prior literature, we chose a quantitative approach and tested the relationships between, on the one hand, specific lean organizational principles, work organization characteristics and management tools - also a lean bundle - and, on the other hand, employees' job satisfaction and health through a national survey (Study 1). We also conducted a retrospective case study on the implementation of lean management to better understand the 
consequences of the decoupling between lean ideal and lean practices on employees' job satisfaction and health (Study 2). This qualitative approach pointed out the difference between discourse and practices when setting up the lean in a context.

The quantitative study left out "the dynamics of meaning-making, both sense-making and sense-giving in a local context" (Bartunek and Seo, 2002: 239). To overcome these issues, we used the results of our retrospective case study (Study 2) to get a contextual understanding of the phenomenon under scrutiny in focusing on people's experiences and the meanings they place on events, processes and their work environment (Gray et al., 2011; Kiessling and Harvey, 2005). We integrated the results of Studies 1 and 2 to triangulate conclusions across studies (Kidder and Fine, 1987) in Study 3 and to develop an initiation framework, i.e. "the recasting of questions or results from one method with questions or results from the other method" (Greene et al., 1989: 259).

\section{A quantitative approach (Study 1): main effects of a bundle of lean organizational principles, work organization characteristics and management tools on employees' job satisfaction and health}

What are the main effects of a bundle of lean organizational principles, work organization characteristics and management tools on employees' job satisfaction and health? To answer this question, we conducted a formal quantitative test of the effects of a bundle of lean organizational principles (just-in-time, $m u d a$ ), work organization characteristics (job rotation, standardization, quality management, teamwork, problem-solving demand) and management tools (5S, five whys, Poka-yoke) on employees' job satisfaction and health (i.e., work health, general health and depression). As mentioned above, to tackle the issues raised by previous studies, we decided to use the data from a national survey to be able to generalize our results above specific activity sectors and occupational groups. 
The core just-in-time lean organizational principle significantly reduced time taken for employee micro-breaks, which they find necessary to allow their muscles and joints to recover (Landsbergis et al., 1999a). Moreover, with the just-in-time system, employees must comply with rigid cycle times and are expected to adjust immediately to changes as demand fluctuates. Thus, stress levels were higher among line operators under just-in-time systems (Klein, 1989). We could therefore expect just-in-time to be negatively correlated to health and job satisfaction. The muda principle (reduction of wastes) led to the removal of buffer stocks and thus significantly reduced the length of employees' micro-pauses (Haynes, 1999; Landsbergis et al., 1999a). We now propose to test hypothesis 1 :

Hypothesis 1a: Just-in-time principle is negatively correlated to job satisfaction and health.

Hypothesis $1 b$ : The muda principle is negatively correlated to job satisfaction and health. As mentioned in the literature (Jorgensen et al., 2005; Padula et al. 2017), we expected job rotation to be positively correlated to health at work and job satisfaction. Regarding standardization, Jackson and Mullarkey (2000), in a study in garment manufacture, have suggested that lean standardization leads to a significant decrease in method control, which "reflects the level of influence individuals have over the methods to use in completing given tasks" (Jackson and Mullarkey, 2000: 233) and timing control, which "reflects the extent of influence individuals have over the initiation, pacing, and completion of given tasks" (Jackson and Mullarkey, 2000: 233). Yet, the empirical study of Jackson and Mullarkey (2000) has supported the idea that individual method and timing controls are positively correlated with job satisfaction and negatively with job-related strain. Thus, we expected restricted method and timing controls to be negatively correlated with health at work and job satisfaction. Concerning quality management ${ }^{3}$, in lean management system, employees have to identify and adjust

\footnotetext{
${ }^{3}$ We examined the effect of quality management via an index: ISO 9000 standards. ISO 9001 norms are a good indicator for measuring quality management (Kojima and Kaplinsky, 2004). ISO 9000 standards, in particular ISO 9001 standards, include
} 
defective parts and report them through a written report to the quality control department. Quality management directly influences work organization through standardization of procedures (Coutrot, 1999). We call "standardization of procedures" the standardization of the ways of precisely reporting one's work, not only the results of one's work but also the ways one precisely follows standardized work processes. Prior literature has supported the idea that quality management "philosophy" fosters improvement of the working environment and health (Rahimi, 1995). This idea is in line with the principles of ISO 9000 certification (more specifically ISO 9001 certification), which contains indications on the working environment. Several studies have suggested that quality management has a positive influence on job satisfaction (Martinez-Costa et al., 2009; Morrow, 1997; Terziovski et al., 1997). Thus, we expect quality management to be positively related health at work and job satisfaction. With regard teamwork, according to Niepce and Molleman (1998), Procter and Radnor (2014), this lean work organization practice allows employees to take part in some areas of decision making (e.g., quality, work procedures) but also involvement mechanisms (e.g., quality circles, improvement teams). Teamwork may, therefore, have a positive influence on job satisfaction and health. Finally, the rise of problem-solving demand caused by lean implementation increases job-related strain and decreases job satisfaction (Jackson and Mullarkey, 2000). We therefore propose:

Hypothesis $2 a$ : Job rotation is positively related to job satisfaction and health.

Hypothesis $2 b$ : Work standardization is negatively related to job satisfaction and health.

Hypothesis 2c: Quality management is positively related to job satisfaction and health.

Hypothesis $2 d$ : Teamwork is positively related to job satisfaction and health.

Hypothesis 2e: Problem-solving demand is negatively related to job satisfaction and health

the principles of quality management. Furthermore, the implementation of quality management is often a prerequisite for obtaining the ISO 9000 standard (Whithers et al., 1997). 
Lean tools - such as 5S program, Ishikawa (1985) quality tools or seven wastes - are positively associated with job satisfaction (Rodriguez et al. 2016). Thus, we propose:

Hypothesis 3: Lean tools (5S, five whys, Poka-yoke...) are positively related to job satisfaction and health.

To our knowledge, only two quantitative studies compared the effect of lean bundles on employees' attitudes and health (Lewchuck and Robertson, 1996; Valeyre et al., 2009). These last studies show that lean bundle is negatively related to job satisfaction and health. Moreover, the intensification of work is presented and empirically verified as one of the main consequences of lean management (Haynes, 1999; Landsbergis et al., 1999a; Lewchuk and Robertson, 1996). Thus, we propose:

Hypothesis 4a: Lean bundle is negatively related to job satisfaction and health.

Hypothesis 4b: Work intensification mediates the negative relationship between lean bundle and job satisfaction or health.

\section{Method}

Quantitative study: data from a French national survey

We used the data from the 2016-2017 national French SUMER survey, which examined 26,494 employees. The 2016-2017 SUMER survey was jointly conducted by the DARES (Directorate for the Coordination of Research, Studies and Statistics) and the General Directorate of Labor of the French Ministry of Labor, Social Relations, Family and Solidarity. The SUMER survey assessed employees' exposure to occupational risks and illnesses, wellbeing, and working conditions (Coutrot et al., 2018). It was conducted by a network of 1200 voluntary occupational physicians, in charge of compulsory medical examinations of employees, who collected the data from a random sample of their employees. The data were representative of the 24.8 million 
French employees. This edition obtained the label of general interest and statistical quality issued by the National Council of Statistical Information (CNIS). We present the items used in the analysis to define the variables in Table 4.

Table 4 about here

Given the ordinal nature of work health, general health and job satisfaction, we used ordered logistic regressions. For depression, as it was treated as a continuous variable, we used OLS regressions. To test the effect of a mediator (work intensification), we used Kenny et al. (1998) procedure $^{4}$, which fits logistic regression. In order to confirm that the independent variable was significantly related to the mediator (i.e. the second condition to fulfill in order to confirm a mediation effect according to Kenny et al. (1998)), we used an OLS regression on the mediator (work intensification) as it was a continuous variable.

Results

Table 5 presents the intercorrelations matrix for all variables. The correlations suggest that multicollinearity should not be a problem as the correlation coefficients are below 0.4.

Table 5 about here

Ordinal logistic regression analyses were performed to test the hypotheses. The results are presented in Tables 6,7 and 8 .

Tables 6,7 and 8 about here

\footnotetext{
${ }^{4}$ We did not use the mediation test procedure developed more recently by Preacher and Hayes (2004) because it relies on the assumptions of an interval-dependent variable and the use of a regression model based on ordinary least squares estimation. In our case, the dependent variable was an ordinal and we performed an ordered logistic regression.
} 
Regarding lean organizational principles, just-in-time was negatively linked to work health (Table 6, Model 2, $\beta=-.210^{* * *}$ ), general health of employees (Table 6, Model 3, $\beta=-.117^{*}$ ) and depression (Table 6 , Model 4, $\beta=-.036^{* *}$ ) but not significantly linked to job satisfaction. Thus, hypothesis 1a was partially confirmed. Muda was positively associated with work health (Table 6, Model 2, $\beta=.086^{*}$ ) and job satisfaction (Table 6 , Model $1, \beta=.175^{* * *}$ ) but not significantly linked to general health and depression. Hypothesis $1 \mathrm{~b}$ was partially confirmed. Regarding lean work organization characteristics, job rotation was negatively associated with work health, general health and positively associated with depression (Table 6, respectively, Model 2, $\beta=-.123 * * * ;$ Model 3, $\beta=-.120 * * * ;$ Model 4, $\beta=.032 * * *$ ) but not significantly linked to job satisfaction. Hypothesis 2a was not supported. Work standardization was negatively associated with job satisfaction, work health, general health and positively associated with depression (Table 6, respectively, Model 1, $\beta=-.584 * * *$; Model 2, $\beta=-$ $.418^{* * *}$; Model 3, $\beta=-.363^{* * *}$; Model 4, $\left.\beta=.131^{* * *}\right)$. Thus, hypothesis $2 \mathrm{~b}$ was confirmed. Quality management was negatively associated with job satisfaction, work health, general health, and positively associated with depression (Table 6, respectively, Model 1, $\beta=-.079 *$; Model 2, $\beta=-.154 * * * ;$ Model 3, $\beta=-.081 * ;$ Model 3, $\left.\beta=.030^{* * *}\right)$. Thus, hypothesis 2c was not supported. Teamwork was positively associated with job satisfaction, work health (Table 6 , respectively, Model 1, $\beta=.120^{* *}$; Model 2, $\beta=.099^{*}$ ) but not significantly linked to general health and depression. Thus, hypothesis $2 \mathrm{~d}$ was partially supported. Problem-solving demand was not significantly linked to any employee outcomes variable. Those results did not support hypothesis $2 \mathrm{e}$.

Concerning lean management tools, we found that lean tools were not significantly linked to employee outcomes variables. 
About lean bundle, we found that lean bundle was negatively associated with work health, general health (Table 7, respectively, Model 6a, $\beta=-.276^{*}$; Model 7a, $\beta=-.302^{* *}$ ) but not significantly linked to depression, partially supporting hypothesis 4a.

In compliance with the mediation effect testing procedure described by Kenny et al. (1998), we first tested whether lean bundle had a significant relation with employee outcomes variables, which was the case for both work health and general health variables. (Table 7, respectively, Model $6 \mathrm{a}, \beta=-.276^{*}$; Model 7a, $\left.\beta=-.302^{* *}\right)$. We then tested the mediation through work intensification by testing steps 3 and 4 of Kenny et al.'s (1998) procedure. We found that the estimated parameters associated with the lean bundle variable decreased when we included the work intensification variable for both outcomes variables, work health (Table 7, Model 6a, $\beta=$ $-.276^{* *} \rightarrow$ Model 6b, $\beta=-.199(\mathrm{~ns})$ ) and general health (Table 7, Model 7a, $\beta=-.302 * * \rightarrow$ Model $\left.7 \mathrm{~b}, \beta=-.259^{*}\right)$. Lean bundle had a significant negative relation with work intensification in the OLS regression (Table 8 , Model $9, \beta=-.075^{*}$ ). The mediation effect of work intensification in the relationship between lean bundle and both work health and general health was therefore demonstrated. Thus, Hypothesis $4 \mathrm{~b}$ was partially supported.

\section{Discussion}

First, our results demonstrated that work standardization - a lean work organization characteristic - was negatively associated with both job satisfaction, work health and general health, and positively associated with depression. We could interpret these results through a loss when determining work methods for employees due to work standardization, which induces dissatisfaction and higher job-related strain (Jackson and Mullarkey, 2000). Moreover, just-in-time core lean organizational principle was negatively associated with both work health and general health, and positively associated with depression. Our two last results on work standardization and work intensification could be interpreted using Karasek and Theorell (1990) Job Strain Model. The lean system induces employees to be exposed to a high-strain job 
combining high job demand and low job control. In the lean system, high job demand results from customer pressure (through the just-in-time system) and time pressure due to the absence of buffers. Complementary statistical analyses indicated that just-in-time was positively associated to work intensification, which acts as a mediator in the relationship between just-intime and work health, and general health and depression ${ }^{5}$. Job control was low due to work standardization in the lean system.

Contrary to what we expected, the muda lean principle was positively associated with job satisfaction and work health. This result could be explained by "the pride of a well-done job" (Clot, 2010: 39). In order to reduce waste in the production process, it could be considered by employees as one of the dimensions of a well-done job.

Secondly, job rotation was associated with lower health levels. Therefore, job rotation did not have the desired effects on employees' health. This result could be explained by the fact that the development of job rotation is seldom combined with that of 'multi-skilling' (the possibility of performing complex tasks by using various skills), especially in lean management (Babson, 1993; Landsbergis et al., 1999a). Thus, while on average $31.8 \%$ of the survey population had high monotonous tasks, this percentage rose to $36.5 \%$ for employees exposed to job rotation. Likewise, while on average $22.8 \%$ of the survey population had high skill demanding jobs, this percentage decreased to $21.4 \%$ for employees exposed to job rotation. Thus, these results empirically confirmed the assertion of Jorgensen et al. (2005: 1722): "If an employee rotates from a job that places excessive stress on the low back to another job that also places stress on the low back, the rotation scheme may be ineffective in controlling risk of injury to the low back".

\footnotetext{
${ }^{5}$ These complementary statistical analyses can be sent if necessary.
} 
Thirdly, we assumed that quality management was associated with higher levels of job satisfaction and health. However, quality management was negatively associated with job satisfaction, work health and general health. It may be due to the domination of one of the two antagonist explanations: i) the first explanation is that the quality management "philosophy" improved the working environment and health at work (Rahimi, 1995); ii) The second antagonist explanation is that quality management led to an increase in physical strenuousness as employees had to strictly follow quality process (Karltun et al., 1998). Thus, the second explanation was confirmed by our results. In addition, quality management was associated with job dissatisfaction. We will explore this unexpected result in integrating quantitative and qualitative analyses below.

Finally, when discussing the main effects of lean management on employees' attitudes and health, we confirmed the claim of some academics (Babson, 1993; Haynes, 1999; Landsbergis et al., 1999a; Lewchuk and Robertson, 1996). Lean management, as a bundle of organizational principles, work organization and management tools, had a deleterious main effect on work health and general health.

Our literature review pointed out the methodological weaknesses of previous researchers (e.g., the samples on which these studies are based were too small or too specific to one activity sector; few presentations of the lean work organization characteristics were implemented) on the lean/well-being relationship. Our quantitative empirical study has tried to tackle these weaknesses in studying the effects of organizational principles, work organization and management tools on employees' job satisfaction and health on a large-scale survey. However, our quantitative results just detected statistical regularities but did not examine the "how" of these relationships. In addition, we need to clarify the unexpected result on the quality management-job satisfaction relationship by integrating quantitative and qualitative analyses. 


\section{Study 2: How could a decrease in employees' job satisfaction and health be caused by the decoupling between lean ideal theory and lean practices?}

We conducted a case study in a lean manufacturing plant considered as a pilot by the managing director of a French railway company in order to understand the effects of the decoupling between lean ideal and lean practices on employees' job satisfaction and health.

\section{Study design}

The study was carried out in a French railway company's maintenance business with 400 employees, where one of the production units of this business had undergone organizational change between late 2005 and early 2006, involving the introduction of lean management. For this case study, we chose a company that had implemented lean management where blue-collar employees were overrepresented. Blue-collar employees are a priori most concerned by the lean system $(37.7 \%$ of machine operators and assemblers are working in a form of lean system compared to $28.8 \%$ for the overall population according to Lorenz and Valeyre, 2006). The data were collected between February and May 2009, using thirteen face-to-face semi-structured interviews carried out with employees (see Table 9), HR managers, unit and line managers, trade union representatives, members of the occupational health department and a consultant, who participated in the implementation of the new work organization (see the interview protocol in Appendix 1). The interviews were conducted during working time in a closed room and lasted between one and one and a half hour. All interviews were digitally recorded and transcribed verbatim. During this period, we also carried out non-participant observation for three days. We were wearing the uniform of the railway company to help socialize with employees. We took extensive field notes on the lean work environment, on the interactions between employees and between line managers and employees, and, on the way, work was

done. We also interpreted information drawn from documentary analysis (internal documentation supplied by the HR department, the occupational health department and trade 
unions). To identify lean organizational principles, lean work organization characteristics and lean management tools, we used a priori categories based on the literature review on lean definitions presented in Table 2.

We also looked at job satisfaction and health indicators from social annual reports after the lean implementation so as to have a clear chain of evidence (Pratt, 2009; Yin, 2003). We thus followed the evolution of sickness absenteeism and work-related musculoskeletal disorders (WMSDs) between 2006 and 2008, just after the implementation of lean.

\section{Data analysis}

The interviews were analyzed through a template analysis (King, 2004). This is a method whereby "the researcher produces a list of codes ('template') representing themes identified in their textual data. Some of these will usually be defined a priori, but they will be modified and added to as the researcher reads and interprets the texts. The template is organized in a way which represents the relationships between themes, as defined by the researcher, most commonly involving a hierarchical structure" (King, 2004: 256). Compared to the prescriptive coding procedure of Strauss and Corbin (1990), template analysis is, on the whole, a flexible technique with fewer specified procedures, allowing researchers to tailor it to match their own requirements (King, 2004). We followed a deductive and inductive approach, using a priori categories from the constructs in the quantitative study (Study 2) and the lean management literature on the definition of lean while also identifying new codes emerging from the data. Thus, the initial template was developed using a priori codes generated from the hypotheses in Study 2, and Table 2 on the definition of lean. The initial template was used to work through the transcripts and identify relevant themes from the text, which were then coded. Template development was an iterative process as "once the initial template is constructed, the researcher must work systematically through the full set of transcripts, identifying sections of text which are relevant to the project's aims, and marking them with one or more appropriate code(s) from 
the initial template. In the course of this, inadequacies in the initial template will be revealed, requiring changes of various kinds" (King, 2004: 261). The final version of the template was then applied to all the transcripts. For reliability purpose, both authors were involved in this process, each working independently in the initial stage whereby initial template was used to work through the transcripts and identify relevant themes from the text. Then both authors, after discussion, converged to a final template. A copy of the final template can be found in Appendix 2. Appendix 3 summarizes the coding scheme.

Table 7 about here

Results

One of the goals of reorganization was to improve the "smooth flow" (consulting firm document outlining the reorganization project) between the different repair operations for a part (disassembly, cleaning, appraisal, assembly, testing). More specifically, the aim was to prevent a part from returning to a previous step in the repair process (for example, returning an assembly piece to appraisals) or moving back and forth between testing and assembly, so as to limit flows between the different repair operations. Several properties of the lean management model as described by leading researchers (Liker, 2004; Monden, 1983; Ohno, 1988; Womack et al., 1990, 2003) were introduced in the railway company:

- Upstream stocks (parts to be repaired) were removed. Likewise, downstream stocks (parts repaired) were removed and directly re-deployed to the industrial logistic platform (ILP) once repaired. There is now a downstream-led approach in place.

- A just-in-time system was implemented, with each workstation able to request that the upstream post deliver to them, in good time and in the necessary quantities, the parts that are essential for their activity. 
- The Kanban system or labelling system was implemented. This system allows for an order to be triggered for supplies of "consumables" - "consumables" are components such as screws, washers, and gaskets that are essential to repair the part - as soon as the previous batch starts. When asked, the business unit head (middle-management) replied, "Kanban is everywhere." However, Kanban was not extended to the entire production line. Thus, it was up to the middle management in production logistics support to set the number of parts to be produced by each workstation in order to deliver the parts within the required time limit.

- The Kaizen system (i.e. continuous improvement process of the production system through employee suggestions) was implemented. "Innovation" sheets were made available to employees. Employees could then share their ideas for improvements to the production system and bonuses reward the best employee suggestions. However, in our case study, Kaizen seemed quite far from the participation level of employee teams in Kaizen activities as described by lean leading researchers (Liker, 2004; Monden, 1983; Ohno, 1988; Womack et al., 1990, 2003). The management team used video analyses performed by an ergonomist during a consultancy in the operational unit in 2008 to time the various operations (disassembly, expertise...) for each of the repaired parts:

$$
\begin{aligned}
& \text { An ergonomist came (in 2008) and filmed everything ... The ergonomist came to improve } \\
& \text { working conditions ... And overnight, they asked us to make fifteen parts. That's why it was a } \\
& \text { little painful ... badly perceived. Top management used the ergonomist to increase production } \\
& \text { and it was frowned upon. (employee B) }
\end{aligned}
$$

As observed by Head (2003), Kaizen was instrumentalized to increase work intensity through the input of work-study engineers.

- Quality management was also applied in the new organization. Quality standards (ISO standards) and self-monitoring of work quality were applied. The Ishikawa (1985) approach was also implemented. If the customer is not satisfied with the material received after 
maintenance, an expert writes a report to pinpoint the cause of the problem. A non-conformity sheet is then issued. Corrective action is finally taken.

Two main work organization characteristics presented in Table 2 were not implemented: job rotation and team work. Thus, in the context of our study, if job rotation was an objective displayed by management, reality showed that it was poorly applied. Yet, the literature supports the idea that job rotation helps to increase job satisfaction (Mohr and Zoghi, 2008), and reduce both the risk of musculoskeletal disorders (Jorgensen et al., 2005) and the tiredness caused by the over-division of labor (Hsieh and Chao, 2004). The obvious benefit of job rotation is the increase in skills variety (Womack et al., 2009). Moreover, "the premise of job rotation is that workers rotate from job to job in a given time period, with the objective of minimizing the accumulated biomechanical loading on a particular body part for all workers" (Jorgensen et al., 2005: 1721).

Job rotation is thus considered as a way to reduce work-related musculoskeletal disorders (WMSDs). In our case, where job rotation was not implemented, the number of WMSDs has increased significantly (between 2005 and 2006, in the operational unit studied, the number of MSDs declared by year increased from 2 to 8 ).

Likewise, teamwork, which is a core element of the lean work organization characteristics, was not implemented in the operational unit. Lean teams are expected to significantly upskill shopfloor operators (Womack et al., 1990) as operators are vested with greater responsibility for many tasks (e.g. problem-solving activities, routine maintenance, etc.) that were previously the prerogative of specialist groups (Delbridge et al., 2000). Moreover, there is a strong emphasis on mutual support and cooperation inside lean teams (Womack et al., 1990; Dankbaar, 1997), which leads to increase employees' job satisfaction and health. According to Karasek and Theorell (1990) model of job demand-control-support, social support from colleagues is negatively associated with job-strain and sickness absenteeism. In our case study, implementing 
lean management may have increased sickness absenteeism. Although it cannot be ascertained, several arguments point in this direction:

- the importance of the phenomenon: between 2006 and 2008, the number of sick leaves increased by $82 \%$ and the cumulative absenteeism by 21.1 points. No other change in the organization could explain this increase;

- maintaining the phenomenon: the increase in absenteeism was not transient. Conversely, it was maintained for three years after the reorganization;

- the testimonies of the agents who knew the previous work organization showed a real deterioration of work organization in terms of autonomy, cognitive content of work and work density.

This rise in sickness absenteeism might be explained by the non-implementation of lean teams, which may be associated with a lack of colleague's support. However, we did not notice a lack of mutual support and cooperation between employees:

$$
\begin{aligned}
& \text { We give each other a hand and give advice and everything ... So we still manage to get the trick } \\
& \text { going ... I feel supported though, so if I need to... I can ask colleagues for help (employee C). }
\end{aligned}
$$

Moreover, during the direct observation, older employees significantly supported younger ones, and transmitted their "know-how" and "tricks of the trade" to them.

\section{Discussion}

This case study indicated that lean implementation could be associated with two health problems: work-related musculoskeletal disorders (WMSDs) and sickness absenteeism. Moreover, it provides qualitative support for the proposition that job satisfaction and health problems are caused by the decoupling between lean ideal and lean practices. First, Kaizen, far from the democratic participation described by lean leading researchers (Liker, 2004; Monden, 1983; Ohno, 1988; Womack et al., 1990, 2003) was instrumentalized to increase work intensification. Yet, work intensification has strong negative effects on employees' job 
satisfaction and health. Secondly, the number of work-related musculoskeletal disorders (WMSDs) increased significantly between 2005 and 2006. This may be explained by the fact that job rotation, a core lean job characteristic, was not implemented. Job rotation is considered as a way to reduce WMSDs (Womack et al., 2009). Thirdly, the lack of lean teams could explain the rise in sickness absenteeism after lean implementation. However, some elements qualified this lean decoupling effect on employees' job satisfaction and health. One might have been expected no mutual aid between employees since lean teams were not implemented. Yet, that was not the case. We did not observe a lack of mutual support and cooperation between employees. Moreover, job rotation does not automatically reduce WMSDs. As noticed by Jorgensen et al., (2005), if an employee rotates from a job that puts excessive stress on a part of the body to another job that also places stress on the same part of the body, the rotation scheme may be ineffective in controlling the risk of injury. We will investigate this issue in Study 3 .

\section{An integrative examination of the qualitative and quantitative results (Study 3)}

To complement the quantitative approach, we reexamined the qualitative but also the quantitative data to explore how lean might influence employees' job satisfaction and health. To identify lean organizational principles, lean work organization characteristics, lean management tools and the process whereby they are related to health at work and job satisfaction, we reused the same template analysis as in Study 1.

Results

1. The consequences of just-in-time on employees' job satisfaction and health: a vicious cycle The results of the case study shed light on the mechanisms whereby the time pressure reinforced in lean management reduced employees' health at work and job satisfaction. Since the reorganization that had led to the implementation of lean management, the number of MSDs 
increased significantly (between 2005 and 2006, in the operational unit studied, the number of MSDs declared every year went from 2 to 8 ). The implementation of the lean principle of justin-time, by speeding up the production cycle, led to an increased pace of work. The aim of the reorganization project, named "performance project" was to boost productivity by $7 \%$ per year between 2006 and 2008, which led the operational unit's leadership to implement faster work processes by eliminating wasting time - such as cutting moving time of employees during a day through the implementation of U-turn layout - and reducing production times used in the former work organization by the same percentage:

Since 2006, times have decreased by 7\% per year (business unit head, middle-management) They (the leadership) have decreased UTs (unit times) but now there are always some parts in surplus while others always run out... Often they (the employees) don't even have enough time any more to make the part (consultant that participated in the reorganization).

This increased time pressure heavily impacted employees. Template analysis of interviews confirmed this observation:

We have to rush; they're always asking more and more from us (employee D).

We started with eight parts (eight parts to repair per day), then we moved on to ten parts and then he (the middle manager in production logistics support) wanted us to repair fifteen parts; (silence); per day! And that was very tough to achieve! We could do that for just one week, but for our whole working life, no way! So, we complained a little bit about that, I have to say. We downed tools (we rebelled against the line managers), if you like, to make our point... Fifteen parts is a huge amount! (employee B).

These quotes highlight how lean management through the elimination of "wasting times" turns to significantly increase the work pace. Thus, it makes it impossible for employees to take micro-breaks in order to rest their bodies, thus leading to deteriorate their health. 


\section{Work standardization is detrimental to health at work and job satisfaction}

The implementation of lean management in the railway company's maintenance business increased work standardization. After the implementation of lean management, for each work station, there appeared a type of standardized listing for every task of that job, the specific order in which you are supposed to perform the tasks, and the amount of time that is allocated to do each task. Thus, employees' work method control was very weak at each work station. This very limited choice of work methods increased the monotony of work. We identified several remarks in informal exchanges with a young employee during non-participant observation that revealed this monotony:

We leave our brain at the door (young employee, one year of seniority).

The young agent (one-year tenure) uttered the following sentences:

We don't try any more to understand why it does not work. We do the absolute minimum!

Timing control was also reduced after the implementation of lean management. Careful time studies were conducted to optimize the production process to eliminate wasting time. Furthermore, the implementation of just-in-time did lead to a marked reduction in employees' work predictability. Just-in-time led employees to repair the amount of parts requested by the upstream work station in good time without knowing what type of parts, and how many, will next be requested by the upstream work station to be repaired. This near absence of predictability reduced their timing control. As a result, this reduced timing control did not allow employees to choose or modify their working pace when carrying out their work, which is in line with their levels of capacity and fatigue:

(During the reorganization of the operational unit) we asked for five days of job predictability, that's for a guy to know, when he starts a job, what he's going to be doing during the next five days (...). We reached an agreement (with the leadership) for three days. But in reality, it's one day (...) No one works in a linear way: we work in fits and starts, depending on the 
format, depending on fatigue, depending on whatever... The problem is that often the boss (the middle manager in production logistics support) is back on the attack at the end of the day: "why haven't you made ten parts?". It's important to keep hold of this flexibility, for the worker to be on top of his working speed, even if he isn't in charge of the quantity to be produced (trade union delegate, member of the Health and Safety Committee).

These quotes elucidate how work standardization, a lean job characteristic cornerstone, reduces method and timing controls, and finally increases job dissatisfaction and deteriorates employees' health.

\section{A clarification of the unexpected effects of quality management}

The results of the case study shed light on the reasons why quality management leads to job dissatisfaction. In the new lean system, employees had to complete a conformity file after testing the repaired part. They also had to fill in a daily production sheet. On this daily production sheet, they reported on the number of parts repaired per employee, the type of operation carried out (disassembly, cleaning, appraisal, assembly, testing) as well as any problem encountered by the employee during their work (e.g. parts missing, or problem with a work tool). Finally, they had to fill in a parts output sheet.

The new organization of work therefore led to increasing volumes of work, resulting from the introduction of quality management:

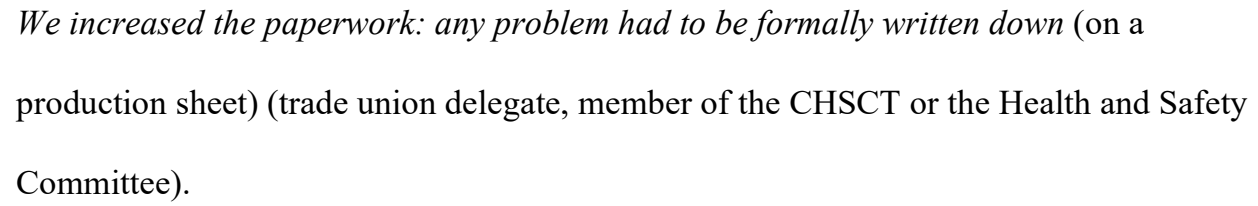

Quality management leads to an expanding raft of bureaucratic procedures associated with formal documentation (Dawson, 1998; Dhaouadi et al., 2008). All these formalized procedures, associated with quality management, increase the density of work, i.e. the volume of reporting tasks. Employees are not satisfied with this high level of reporting tasks: 
We do too much paperwork. What's more, we double up on our work. For every part I've done, I've engraved a number onto it, put that number onto a label and then attached it to the part. Then..., I fill in the daily file (a conformity file that has to be filled in after testing the part), where I write the part number, the "symbol" (type of part repaired) of the part and the date when I started it, in order to show that it was me who did it. Then, I fill in a daily sheet (daily production sheet) where I re-enter the same information. Next, when I put the part on the palette to be taken away, I re-enter the same information (parts output sheet), and then there you go...! You spend as much time doing paperwork as actually doing the job! And what's more, I have to consult a monthly table to check the number of parts completed and delivered! So, that makes five entries of the same information. I think we could find another solution (employee C).

We tried here to shed light on an unexpected outcome concerning the relationship between quality management and job satisfaction. The empirical results of several studies might suggest that quality management has a positive influence on job satisfaction (Martinez-Costa et al., 2009; Morrow, 1997; Terziovski et al., 1997). We have empirically observed the opposite, which is of course an unexpected outcome. Our qualitative material gave us some explanation, that is, the increased volume of work caused by quality management. A principle emerged from our analysis, and, if this principle turns out to be true, then it could explain this unexpected result. The principle is as follows: quality management leads to increased volume of reporting tasks (i.e. an increased work density, Ughetto, $2007^{6}$ ), which in turn leads to employees' job dissatisfaction. The latter result is in keeping with the analyses conducted by Karltun et al. (1998). They have shown that the ISO 9000 certification "has created (in the six firms studied) a complicated and rigid system which caused a heavy workload, bureaucracy and difficulties to influence and obtain changes (...). The opinion that additional tasks, such as documentation,

\footnotetext{
${ }^{6}$ Work density corresponds to the fact that the same task can lead, in its achievement, to perform in parallel other micro-tasks. This is the case when the employee must not only perform an action but at the same time report on it in reporting documents (Ughetto, 2007).
} 
had increased stress levels was common and supported by the questionnaire results' (Karltun et al., 1998: 229). Furthermore, in a case study carried out in a subsidiary of an automotive supplier, Dhaouadi et al. (2008) have observed that the implementation of quality management leads to an increase in reporting tasks via a significant number of sheets to be completed for the operator (kaizen sheets, efficiency sheets, machine follow-up sheets). The authors of this study have discovered that increased volumes of reporting tasks are in part responsible for the increased stress experienced by employees.

\section{Discussion}

The integrative quantitative and qualitative analyses corroborate and extend the findings from Study 1. The qualitative study helps provide understanding of the underlying dynamics and meaning-making associated with abstract constructs used in the quantitative study, "such as how these are enacted and how they evolve" (Bartunek and Seo, 2002: 240). Importantly, while supporting the negative effect of three lean organizational principles and work organization characteristics - just-in-time, work standardization and quality management - this study extends understanding by revealing how quality management leads to increased work density, which in turn leads to job dissatisfaction. This mixed methods design has been called a “development design” by Bainbridge and Lee (2014).

\section{Overall discussion}

\section{Theoretical, methodological and managerial contributions}

\section{Theoretical contributions}

The study responded to a recent call to clarify the distinct effect of lean context, lean implementation, and lean thinking on job satisfaction and health (Hasle, 2014). To fully understand the phenomenon, we answered two competing research questions: the effects of lean 
management on job satisfaction and health in terms of decoupling and essential effects. We showed that the association of lean organizational principles, work organization characteristics and management tools with employees' job satisfaction and health resulted from both lean decoupling and essential effects.

First, we contributed to lean literature in clarifying the theoretical definition of lean management (see Tables 1 and 3) considered as a bundle, which involved identifying a distinctive coherent combination of lean characteristics in terms of organizational principles, work organization and management tools built around an rationalization logic.

Moreover, this study held several opportunities to influence future research on the essential and decoupling effects of lean management on employees' job satisfaction and health. Firstly, quantitative study 1 highlighted several new results in the lean literature, more especially the effect of lean organizational principles and work organization characteristics on employees' depression. We thus demonstrated that the core lean just-in-time principle was associated with health and depression problems through work intensification. Our quantitative analysis also showed that both core work organization characteristics - work standardization and quality management - were associated with health and depression problems. As mentioned earlier, there are very limited studies on the effects of a bundle of lean organizational principles, work organization characteristics and management tools on employees' outcomes. Moreover, while previous studies were conducted on very specific contexts, based on a large-scale national survey, our statistical analysis clearly demonstrated the negative essential effect of a lean bundle on employees' health.

Secondly, most of the previous studies did not focus on the processes through which lean work organization characteristics and management tools might affect employees' outcomes. The integration of quantitative and qualitative results in study 3 helped us to better understand this process. The results of Study 3 supported the idea that just-in-time leads to the removal of buffer 
stocks, and thus sharply reduces the length of employees' micro-pauses (Haynes, 1999; Landsbergis et al., 1999a). Study 3 results also highlighted the process through which work standardization sharply reduces employees' work methods and timing controls. Study 3 results helped us to explain why, unexpectedly, quality management was negatively linked to job satisfaction and health. Quality management implementation could lead to an expanding raft of bureaucratic procedures that, in turn, might be associated with job dissatisfaction and stress.

Thirdly, our case study (Study 2) shed light on the decoupling of a lean ideal from lean practices but also qualified this decoupling effect. Study 2 also gave some clues on the way this lean decoupling effect could influence employees' job satisfaction and health. Our results converged with those of Lewchuk et al. (2001: 85): "The implementation of lean is uneven, varying between companies and countries. Furthermore, lean management is not associated with increased empowerment or greater employee control over work. On the contrary, employees' report quite different experiences of work effort, health and safety and relations with management, suggestive of differences that vary more between companies than across countries". One explanation offered by Lewchuk et al. (2001: 86) that may have played a part in our case study was that "while managements' articulated strategies of restructuring may ignore the role of labour and, in particular, unions, and may be expressed in a discourse of technical change, contests with unions force managements [may] re-evaluate and reconfigure their restructuring strategies". Another explanation inspired by Meyer and Rowan (1977) was that lean decoupling enables organizations to maintain standardized, legitimating, formal structures in accordance with the lean rational myth while their activities vary in response to practical considerations so as to be more efficient.

\section{Methodological contribution}


To our knowledge, we contributed to the mixed methods research literature. This was the first article to study two competing claims on the lean decoupling and essential effects on employees' job satisfaction and health, combining both quantitative results of a large-scale survey and qualitative results from a retrospective case study. This approach was close to what Hacking (1999: 160) calls a "looping effect", i.e. a positive feed forward cycle, which creates gradual refinements of purpose (Langley et al., 1995). In other words, our analysis of the relationship between quality management and job satisfaction was based on a cumulative progression in which "elements found in earlier events or stages are added to and built on subsequent events or stages" (Van de Ven, 1992: 173).

\section{Managerial implications}

Meanwhile, our results showed that this decoupling strategy might increase efficiency at the expense of employees' health. Moreover, while lean management is spreading in many different private and public activity sectors, this study supported authors that promote a new Quality of Working Life (QWL) research agenda about the changing nature of work and debates about the quality of jobs (Grote and Guest, 2017; Findlay et al., 2013). When organizations rely on subcontractors or the use of temporary work, this study emphasized the responsibilities of human resources management and organization in the introduction of these practices, as potential sources of occupational health deterioration. In fact, a paradox appeared: these intensive practices implemented in the organization were part of a short-term outlook, but they were repeated over time for employees through the repetition of lean work experiences in different subcontractors. Therefore, the inescapable adaptation of practices for each organizational context should not obscure the double adaptation that must support employees: 1) to these new practices, and 2) to different subcontractors' organizational contexts that appeal to a flexible workforce. The risk is that the required flexibility can have long-term effects, 
without any organization bearing the responsibility for the deterioration of employees' health. This permanent injunction to employees' flexibility in the context of lean and outsourcing has to take into account the potential risk of damaging their long-term health and the need to question the organization's responsibility in the implementation of lean.

\section{Limitations and future research}

We should however consider some limitations in our findings that we could have enlarged to the mixed methods debate.

First, we should examine the difficulties of implementing mixed methods within time (Onwuegbuzie and Leech, 2005). To what extent could a quantitative analysis carried out upstream of a qualitative analysis obscure significant phenomena? Here, in view of our results, the problem might be overcome by subsequently reformulating a new research question, thus going beyond the contributions made by literature on lean management alone.

Second, there still seems to exist "major empirical challenges in searching for and measuring bundles" before understanding the overlapping problem or interdependent practices (Guest, Conway and Dewe, 2004: 81). Future research with mixed methods should possibly help. Yet, about epistemological criticism from a number of authors who query the validity of results from mixed methods, our results lent further support to the theory put forward by authors such as Johnson et al. (2007). The use of different epistemologies should be considered in the wake of the thinking espoused in Peirce's pragmatic philosophical line (Johnson et al., 2007), in order to generate results which cannot be obtained through the use of a single paradigm. Future research should investigate these issues.

\section{Conclusion}

To conclude, our study offered a deep empirical-based investigation of two competing claims on the lean decoupling and essential effects on employees' job satisfaction and health. Our study highlighted how implementing a set of lean organizational principles, work organization 
characteristics and management tools could be a problem for employees, and how it could affect their health. Finally, this study built on specific mixed-methods research design suggesting that the integration of quantitative and qualitative methods and results are needed to explore complex intertwined phenomena in the management and human resources area.

\section{References}

Althaus, V., Kop, J. L., \& Grosjean, V. (2013). Critical review of theoretical models linking work environment, stress and health: Towards a meta-model. Le Travail Humain, 76, 81-103.

Anderson-Connolly, R., Grunberg, L., Greenberg, E. S., \& Moore, S. (2002). Is lean mean? Workplace transformation and employee well-being. Work, employment and society, 16(3), p.389-413.

Arlbjorn, J.S., \& Freytag, P.V. (2013). Evidence of lean: a review of international peer-reviewed journal articles. European Business Review, 25, 174-205.

Babson, S. (1993), Lean or Mean: The MIT Model and Lean management at Mazda. Labor Studies Journal, 18, 3-24.

Bainbridge, H. T. J., \& Lee, I. (2014). Mixed Methods in HRM research. In K. Sanders, J. Cogin and H. T. J. Bainbridge (Eds.), Research Methods for Human Resource Management (pp.15-42). Third Avenue, NY : Routledge.

Bamberger, S. G., Larsen, A., Vinding, A. L., Nielsen, P., Fonager, K., Nielsen, R. N., \& Omland, Ø. (2015). Assessment of work intensification by managers and psychological distressed and nondistressed employees: a multilevel comparison. Industrial health, 53, 322-331.

Bartunek, J.M., \& Seo, M. G. (2002). Qualitative research can add new meanings to quantitative research. Journal of Organizational Behaviour, 23, 237-242.

Berggren, C., (1992). Alternatives to lean production: work organization in the Swedish auto industry. ILR Press, Ithaca, NY.

Bertrand, T., \& Stimec, A (2011). Santé au travail. Voyage en pays de lean management. Revue Française de Gestion, 214, 127-144.

Bouville, G., \& Alis, D. (2014). The effects of lean organizational practices on employees' attitudes and workers' health: evidence from France. The International Journal of Human Resource Management, 25(21), 3016-3037.

Boxenbaum, E., \& Jonsson, S. (2008). Isomorphism, Diffusion and Decoupling. In R. Greenwood, C. Oliver, K. Sahlin, \& R. Suddaby (Eds.), The SAGE Handbook of Organizational Institutionalism (pp. 78-98). London: SAGE Publications.

Carter, B., Danford, A., Howcroft, D., Richardson, H., Smith, A., \& Taylor, P. (2013). 'Stressed out of my box': employee experience of lean working and occupational ill-health in clerical work in the UK public sector. Work, Employment \& Society, 27, 747-767

Clot, Y. (2010). Le travail à cœur. Pour en finir avec les risques psychosociaux. Paris, La Découverte. Coutrot, T. (1999). Critique de l'organisation du travail. Paris, La Découverte.

Coutrot T., Memmi S., Rosankis E., Sandret N., Léonard M., Morand S., Tassy V. (2018). L'enquête SUMER 2016-2017 : bilan de la collecte. Références en Santé au Travail, $\mathrm{n}^{\circ} 156$, INRS.

Conti, R., Angelis, J., Cooper, C., Faragher, B., \& Gill, C. (2006). The effects of lean production on worker job stress. International Journal of Operations and Production Management, 26, 1013-1038. Creswell, J.W. \& Plano Clark, V.L. (2007). Designing and conducting mixed methods research. Thousand Oaks, CA: Sage.

Cullinane, S. J., Bosak, J., Flood, P. C., \& Demerouti, E. (2014). Job design under lean manufacturing and the quality of working life: a job demands and resources perspective. The International Journal of Human Resource Management, 25, 2996-3015.

Dankbaar, B. (1997). Lean production: Denial, confirmation or extension of sociotechnical systems design? Human Relations, 50,567-583 
Dawson, P. (1998). The rhetoric and bureaucracy of quality management. A totally questionable method ? Personnel Review, 27, 5-19.

Delbridge, R., Lowe, J., \& Oliver, N. (2000). Shopfloor responsibilities under lean teamworking. Human Relations, 53, 1459-1479.

De Treville, S., \& Antonakis, J. (2006). Could lean production job design be intrinsically motivating? Contextual, configurational, and levels-of-analysis issues. Journal of Operations Management, 24, 2, 99-123.

Dhaouadi I., El Akremi A., \& Igalens J. (2008). Une analyse critique du management par la qualité totale : implications pour la GRH. Revue de Gestion des Ressources Humaines, 68, 2-22.

Findlay, P, Kalleberg, A., \& Warhurst, C (2013). The challenge of job quality. Human Relations, 66, 441-451.

Fisher, G. G., Matthews, R. A., \& Gibbons, A. (2016). Developing and investigating the use of singleitem measures in organizational research. Journal of Health at work Psychology, 21, 3-23.

Gray, D.E., Ekinci, Y., \& Goregaokar (2011). Coaching SME managers: business development or personal therapy? A mixedmethods study. The International Journal of Human Resource Management, 22, 863-882.

Greene, J. C., Caracelli, V. J., \& Graham, W. F. (1989). Toward a conceptual framework for mixedmethod evaluation designs. Educational evaluation and policy analysis, 11, 255-274.

Grote, G., \& Guest, D. (2017). The case for reinvigorating quality of working life research, Human Relations, 70, 149-167.

Guest, D., Conway, N., \& Dewe, P. (2004). Using sequential tree analysis to search for 'bundles' of HR practices. Human Resource Management Journal, 14, 79-96.

Hacking, I. (1999). The social construction of what ? Cambridge, MA: Harvard Business Press.

Hackman, J. R. \& Oldham, G. R. (1980). Work Redesign. Reading, MA: Addison-Wesley.

Harrison III, R.L. (2013). Using mixed methods designs in the Journal of Business Research, 19902010. Journal of Business Research, 66 (11), 2153-2162.

Hasle, P. (2014). Lean production - an evaluation of the possibilities for an employee supportive lean practice. Human Factors and Ergonomics in Manufacturing and Service Industries, 24, 40-53.

Hasle, P., Bojesen, A., Jensen, P.L., \& Bramming, P. (2012). Lean and the working environment: a review of the literature. International Journal of Operations and Production Management, 32, 829-849. Haynes, A. (1999). Effects of world class manufacturing on shop floor workers. Journal of European Industrial Training, 23, 300-309.

Head, S. (2003). The New Ruthless Economy: Work and Power in the Digital Age. Oxford: OUP.

Hsieh, A. T, \& Chao, H. Y. (2004). A reassessment of the relationship between job specialization, job rotation and job burnout: Example of Taiwan's high-technology industry. International Journal of Human Resource Management, 15, 1108-1123.

Ishikawa, K. (1985). What is Total Quality Control? The Japanese Way. New Jersey: Prentice Hall.

12th cycle of ISO survey of ISO 90 Huselid00 and ISO 14001 certifications (2003). Retrieved from http://www.iso.org/iso/fr/news.htm?refid=Ref864.

Jackson, P. R., Wall, T. D., Martin, R., \& Davids, K. (1993). New measures of job control, cognitive demand, and production responsibility. Journal of Applied Psychology, 78, 753-762.

Jackson, P.R., \& Mullarkey, S. (2000). Lean production teams and health in garment manufacture. Journal of Health at work Psychology, 5, 231-245.

Jorgensen, M., Davis, K., Kotowski, S., Aedla, P., \& Dunning, K. (2005). Characteristics of job rotation in the Midwest US manufacturing sector. Ergonomics, 48, 1721-1733.

Karasek, R., \& Theorell, T. (1990). Healthy work, stress, productivity and the reconstruction of work life. New York: Basic Books.

Karltun, J., Axelsson, J., \& Eklund, J. (1998). Working conditions and effects of ISO 9000 in six furniture-making companies: implementation and processes. Applied Ergonomics, 29, 225-232.

Kenny, D. A., Kashy, D. A. , \& Bolger, N. (1998). Data analysis in social psychology. In Gilbert, D.T., Fiske, S. T. and Lindzey, G., Handbook of Social Psychology, 233-265, New York:McGraw-Hill.

Kidder, L. H., Fine, M. (1987). Qualitative and quantitative methods: When stories converge. In M. M. Mark and R. L. Shotland (Eds.). Multiple methods in program evaluation: New Directions for Program Evaluation 35, 57- 75. 
Kiessling, T., \& Harvey, M. (2005). Strategic global human resource management research in the twenty-first century: an endorsement of the mixed-method research methodology. International Journal of Human Resource Management Journal, 16, 22-45.

King, N. (2004). Using templates in the thematic analysis of texts. in Cassell, C. and Symon, G. (eds), Essential guide to qualitative methods in organizational research, London, England: Sage Publications Limited, 256-270.

Klein, J. A. (1989). The human costs of manufacturing reform. Harvard Business Review, 67, 60-64.

Kojima, S., \& Kaplinsky, R. (2004). The use of lean production index in explaining the transition to global competitiveness: the auto components sector in South Africa. Technovation, 24, 199-206.

Kroenke, K., Spitzer, R. L., \& Williams, J. B. (2001). The PHQ-9: validity of a brief depression severity measure. Journal of general internal medicine, 16, 606-613.

Kunin, T. (1955). The construction of a new type of attitude measure. Personnel Psychology, 8, 65-77. Landsbergis, P.A., Cahill, J., \& Schnall, P. (1999a). The impact of lean production and related new systems of work organization on worker health. Journal of Health at work Psychology, 4, 208-230.

Landsbergis, P. A., Adler, P. S., Babson, S., Johnson, J., Kaminski, M., Lessin, N., ... \& Richardson, C. (1999b). Lean production and worker health: A discussion. NEW SOLUTIONS: A Journal of Environmental and Occupational Health Policy, 8(4), 499-523.

Langley, A., Mintzberg, H.,Pitcher, P., Posada, E., \& Saint-Macary, J. (1995). Opening up Decision Making: The View from the Black Stool. Organization Science, 6, 260-279.

Lewchuk, W., \& Robertson, D. (1996). Working conditions under lean production: a worker-based benchmarking study. Asia Pacific Business Review, 2, 60-81.

Lewchuk, W., Stewart, P., \& Yates, C. (2001). Quality of working life in the automobile industry: A Canada-UK comparative study. New Technology, Work and Employment, 16, 2, 72-87.

Liker, J.K. (2004). The Toyota Way: 14 management principles from the world's greatest manufacturer. New York: McGraw-Hill.

Lorenz, E., \& Valeyre, A. (2006). Organizational forms and innovative performance: a comparison of the EU-15. In Lorenz E and Lundvall BA (eds) How Europe's Economies Learn: Coordinating Competing Models, Oxford; Oxford University Press, 140-161.

MacDuffie, J.P., (1995). Human resource bundles and manufacturing performance: organizational logic and flexible production systems in the world auto industry. Industrial and Labor Relations Review, 48, 197-221.

Martínez-Costa, M., Choi, T.Y., Martínez, J. A., \& Martínez-Lorente, A. R. (2009). ISO 9000/1994, ISO 9001/2000 and TQM: The performance debate revisited. Journal of Operations Management, 27, 495-511.

Meyer, J. W. \& Rowan, B. (1977). Institutionalized Organizations: Formal Structure as Myth and Ceremony. American Journal of Sociology, 83, 340-363.

Mohr, R. D., \& Zoghi, C. (2008). High-involvement work design and job satisfaction. Industrial and Labor Relations Review, 61, 275-296.

Molina-Azorin, J. F. (2012). Mixed methods research in strategic management: Impact and applications. Organizational Research Methods, 15, 33-56.

Monden, Y. (1983). Toyota production system: An integrated approach to just-in-time. Norcross, GA: Industrial Engineering and Management Press.

Morrow, P. C. (1997). The measurement of TQM principles and work-related outcomes. Journal of Organizational Behaviour, 18, 363-376.

Morse, J.M. (1991). Approaches to qualitative-quantitative methodological triangulation. Nursing Research, 40, 120-123.

Niepce W., \& Molleman E. (1998) Work design issues in lean production from sociotechnical systems perspective: Neo-Taylorism or the next step in sociotechnical design?. Human Relations, 5, 259-287.

Ohno, T. (1988). Toyota production system: Beyond large-scale production. Cambridge, MA: Productivity Press.

Onwuegbuzie, A. J., \& Leech, N. L. (2005). On Becoming a Pragmatic Researcher: The Importance of Combining Quantitative and Qualitative Research Methodologies. International Journal of Social Research Methodology, 8, 375-387. 
Padula, R. S., Comper, M. L. C., Sparer, E. H., \& Dennerlein, J. T. (2017). Job rotation designed to prevent musculoskeletal disorders and control risk in manufacturing industries: A systematic review. Applied ergonomics, 58, 386-397.

Parker SK (2003) Longitudinal effects of lean production on employee outcomes and the mediating role of work characteristics. Journal of Applied Psychology, 88(4), 620-634.

Parker, M., \& Slaughter, J. (1995). Unions and management by stress. In: Babson, S. (Ed.), Lean Work: Empowerment and Exploita-tion in the Global Auto Industry. Wayne State University Press, Detroit, 41-53.

Peterson, R.A. (1994). A meta-analysis of Cronbach's coefficient alpha. Journal of Consumer Research, 21, 381-391.

Pratt, M. G. (2009). From the editors: For the lack of a boilerplate: Tips on writing up (and reviewing) qualitative research. Academy of management journal, 52, 856-862.

Preacher, K.J., \& Hayes, A.F. (2004). SPSS and SAS procedures for estimating indirect effects in simple mediation models. Behavior Research Methods, Instruments, and Computers, 36, 4, 717-731.

Procter, S., \& Radnor, Z. (2014). Teamworking under Lean in UK public services: lean teams and team targets in Her Majesty's Revenue \& Customs (HMRC). The International Journal of Human Resource Management, 25, 2978-2995.

Rahimi, M. (1995). Merging strategic safety, health and environment into total quality management. International Journal of Industrial Ergonomics, 16, 83-94.

Rodríguez, D., Buyens, D., Van Landeghem, H., \& Lasio, V. (2016). Impact of lean production on perceived job autonomy and job satisfaction: An experimental study. Human factors and ergonomics in manufacturing \& service industries, 26(2), 159-176.

Sandelowski, M. (2003). The challenges of writing and reading mixed methods studies. In A. Tashakkori and C. Teddlie (Eds.), Handbook of mixed methods in social and behavioral research (pp. 321-350). Thousand Oaks, CA: Sage.

Saurin, T. A., \& Ferreira, C. F. (2009). The impacts of lean production on working conditions: A case study of a harvester assembly line in Brazil. International Journal of Industrial Ergonomics, 39, 403412.

Schouteten, R., \& Benders, J. (2004). Lean production assessed by Karasek's job demand-job control model. Economic and Industrial Democracy, 25, 347-373.

Seppälä, P., \& Klemola, S. (2004). How do employees perceive their organization and job when companies adopt principles of lean production? Human Factors and Ergonomics in Manufacturing, 14, 157-180.

Shah, R., \& Ward, P. (2003). Lean manufacturing: Context, practice bundles, and performance. Journal of Operations Management, 21, 129-149.

Sprigg, C. A., \& Jackson, P. R. (2006). Call centers as lean service environments: Job-related strain and the mediating role of work design. Journal of Occupational Health Psychology, 11, 197-212.

Stewart, P, Richardson, M, Danford, A, Murphy, K, Richardson, T \& Wass, V (2009). We Sell Our Time No More: Workers' Struggles against Lean Production in the British Car Industry. London: Pluto Press.

Strauss, A., \& Corbin, J. (1990). Basics of Qualitative Research: Grounded Theory Procedures and Techniques. Newbury Park: Sage.

Tashakkori, A., \& Teddlie, C. (2d Eds.). (2010). Handbook of mixed methods in social and behavioural research. Thousand Oaks, CA: Sage.

Terziovski, M., Samson, D., \& Dow, D. (1997). The business value of quality management systems certification. Evidence from Australia and New-Zealand. Journal of Operations Management, 15, 1-18. Ughetto, P. (2007). Faire face aux exigences du travail contemporain. Lyon, Anact.

Valeyre, A., Lorenz, E., Cartron, D., Cszimadia, P., Gollac, M., Illessy, M., \& Mako, C. (2009). Working conditions in the European Union: Work organization. Luxembourg: Office for Official Publications of the European Communities.

Van de Ven, A. (1992). Suggestions for studying strategy process: A research note. Strategic Management Journal, 13, 169-191.

Vidal, M. (2007). Lean production, worker empowerment, and job satisfaction: A qualitative analysis and critique. Critical Sociology, 33, 247-268.

Warnous, J. P., Reichers, A. E., and Hudy, M. J. (1997). Overall job satisfaction: How good are singleitem measures?. Journal of Applied Psychology, 82, 247-252. 
Withers, B. E., Ebrahimpour, M., \& Hikmet, N. (1997). An exploration of the impact of TQM and JIT on ISO 9000 registered companies. International Journal of Production Economics, 53(2), 209-216.

Womack, S. K., Armstrong, T. J., \& Liker, J. K. (2009). Lean job design and musculoskeletal disorder risk: A two plant comparison. Human factors and ergonomics in manufacturing \& service industries, 19, 279-293.

Womack J.P., \& Jones D.T. (2003). Lean Thinking. Banish Waste and Create Wealth in Your Corporation. New York: Free Press.

Womack, J. P., Womack, J. P., Jones, D. T., \& Roos, D. (1990). Machine that changed the world. New York: Simon and Schuster.

Yin, R. K. (2003). Case study research: Design and methods (3rd ed.). Applied Social Research Methods Series, vol.5. Thousand Oaks, CA: Sage.

\section{TABLES}

Table 1. Lean characteristics, methods and outcomes for employees

\begin{tabular}{|c|c|c|c|}
\hline Authors & Lean characteristics & Methods & $\begin{array}{l}\text { Effects on health at work and } \\
\text { job satisfaction }\end{array}$ \\
\hline
\end{tabular}

Anderson-Conolly Restructuring, outsourcing, et al. (2002)

\section{reducing inventory,} simplifying production processes and developing cross-functional teams.

Bouville and Alis (2014)

Carter et al. (2013)

Conti et al. (2006)
Responsibility, problemsolving demand, job rotation, standardization, quality management
Mix methods (sequential design): 1. Interviews, focus group, documentary analysis; 2. Quantitative survey (questionnaires) on a large manufacturing company located in the US

Quantitative survey on a French representative national sample of employees
Quantitative and qualitative surveys in the UK clerical sector, more specifically the Her Majesty's Revenue and Customs (HMRC)

Quantitative survey (questionnaires) on a population of UK assemblers
Only the results of the quantitative survey are presented.

Both positive (increase in intensity due to lean implantation increasing stress) and negative effects (increase in skilling due to lean implantation decreasing stress and increasing job satisfaction)

Negative effects (delegation of responsibilities, problem-solving demand, standardization, job rotation) on job satisfaction, employees' intention to stay and health at work, and positive effect (quality management) on health at work. Lean bundle has a negative effect on attitudes and health at work

Strong increase of ill-health symptoms (mental fatigue, physical tiredness, stress, ...) after the implementation of lean

Both positive (team work reduces job stress) and negative effects (pace/intensity increases job stress) waste reduction, Kanban, kaizen, TQM, TPM, standardization 


\begin{tabular}{ll}
\hline $\begin{array}{l}\text { Cullinane et al. } \\
(2014)\end{array}$ & $\begin{array}{l}\text { Just-in-time, TPM, } \\
\text { Employee involvement, } \\
\text { Customer involvement, } \\
\text { reduced set-up times, pull } \\
\text { systems, statistical process } \\
\text { control }\end{array}$ \\
$\begin{array}{l}\text { Jackson and } \\
\text { Mullarkey (2000) }\end{array}$ & $\begin{array}{l}\text { Team work, job rotation, } \\
\text { quality management, no } \\
\text { buffer stocks }\end{array}$ \\
$\begin{array}{l}\text { Lewchuck and } \\
\text { Robertson (1996) }\end{array}$ & $\begin{array}{l}\text { Just-in-time, responsibilities } \\
\text { of direct production } \\
\text { workers, kanban system }\end{array}$ \\
\end{tabular}

Quantitative survey

(questionnaires) in a

pharmaceutical plant

Quantitative Survey

(Quasi-experimentation)

in a garment manufacture

Comparison of four types

of Canadian automotive

organizations: lean

production plants, plants

changing to lean, Ford

mass production plants

and "exploitative" plants.

Quantitative survey on

workers (questionnaires)

Lewchuck et al. (2001)

Shouteten and

Benders (2004)

Parker (2003)

Saurin and

Ferreira (2009)

Not well-defined

Just-in-time, total quality control, total productivity maintenance, standardization of work processes, 5S management

Lean team, assembly lines, workflow integration and formalization

Quantitative survey on five Canadian and UK plants

Quantitative survey (questionnaires) in a company that manufactures and assembles large vehicles.

Quantitative survey (Quasi-experimentation) in a company that manufactures and assembles large vehicles.

Mixed methods (sequential design) in a vehicle plant: 1 .

Interviews, focus group, documentary analysis; 2 . Quantitative survey (questionnaires).

Quantitative Survey (Quasi-experimentation) in a manufacturing company

Quantitative survey (questionnaires) in a call center
Sprigg and Jackson (2006)
Both positive (job resources is positively linked to work engagement) and negative effects (job demand is positively linked to work exhaustion)

No significant effects in terms of job-related strain and job satisfaction

Negative effects: lean workers reported higher intensity of work and higher levels of job stress.

Negative effects (high physical pain, high exhaustion)

Both negative effects (high need for recovery, low satisfaction with job content) and positive (low health/physical reactions)

Negative effects (increased job depression)

Only the results of the quantitative survey are presented.

Positive effects (lean implantation decreases stress and increases job satisfaction)

Both positive (relatively satisfied) and negative effects (higher job stress)

Negative effects (higher jobrelated strain)
Workflow integration (machine-paced through automatic routing of incoming calls), process simplification (standardization through dialog scripting) 


\begin{tabular}{llll}
\hline Vidal (2007) & $\begin{array}{l}\text { Job rotation, team working, } \\
\text { Kaizen, standardization of } \\
\text { work processes }\end{array}$ & $\begin{array}{l}\text { Qualitative survey (semi- } \\
\text { structured and open-ended } \\
\text { interviews) in nine US } \\
\text { lean firms }\end{array}$ & $\begin{array}{l}\text { Negative effect (higher job } \\
\text { dissatisfaction) }\end{array}$ \\
$\begin{array}{l}\text { Womack et al. } \\
(2009)\end{array}$ & $\begin{array}{l}\text { Just-in-time, work teams, } \\
\text { job rotation, quality } \\
\text { management, } \\
\text { standardization, TPM, poka- } \\
\text { yoke, kaizen }\end{array}$ & $\begin{array}{l}\text { Quantitative survey } \\
\text { (quasi-experimentation) } \\
\text { in two automobile } \\
\text { assembly plants (one is } \\
\text { lean, the other is } \\
\text { traditional) }\end{array}$ & $\begin{array}{l}\text { Pusculoskeletal Disorder risks in } \\
\text { the lean plant) }\end{array}$ \\
\hline
\end{tabular}

Source: Adapted from Hasle (2014)

Table 2. Chronological synthesis of a review from leading researchers on the organizational principles, work organization characteristics and management tools associated with lean management

\begin{tabular}{|c|c|c|c|c|}
\hline & $\begin{array}{l}\text { Type of } \\
\text { article/book }\end{array}$ & $\begin{array}{l}\text { Organizational } \\
\text { principles }\end{array}$ & Work organization & Management tools \\
\hline $\begin{array}{l}\text { Monden } \\
\text { (1983) }\end{array}$ & Theoretical work & $\begin{array}{l}\text { - Just-in-time (JIT) } \\
\text {-Production Smoothing } \\
\text { - Shortening Setup Time } \\
\text { - Process Layout for } \\
\text { Shortened Lead Times } \\
\text { - Automation } \\
\text { - Improvement Activities }\end{array}$ & $\begin{array}{l}\text { - Decentralization of } \\
\text { responsibilities } \\
\text { - Standardization (i.e. } \\
\text { restrictive procedural } \\
\text { autonomy) } \\
\text { - Problem-solving } \\
\text { demand } \\
\text { - Job rotation } \\
\text { - Quality management }\end{array}$ & $\begin{array}{l}\text { - U-turn layout } \\
\text { - 5S } \\
\text { - Andon (visual control } \\
\text { device) } \\
\text { - Kanban } \\
\text { - Kaizen } \\
\text { - Quality circles } \\
\text { - Poka-yoke }\end{array}$ \\
\hline $\begin{array}{l}\text { Ohno } \\
(1988)\end{array}$ & $\begin{array}{l}\text { Theoretical and } \\
\text { empirical work } \\
\text { Sample: } \\
\text { comparison of } \\
\text { American and } \\
\text { Japanese firms }\end{array}$ & $\begin{array}{l}\text { - Just-in-time (JIT) } \\
\text { - Analysing and } \\
\text { establishing a production } \\
\text { levelling (mura) } \\
\text { - Analysing and } \\
\text { alleviating waste (muda) } \\
\text { - Analysing and } \\
\text { alleviating overburden of } \\
\text { workers and equipment } \\
\text { (muri) }\end{array}$ & $\begin{array}{l}\text { - Decentralization of } \\
\text { responsibilities } \\
\text { - Standardization (i.e. } \\
\text { restrictive procedural } \\
\text { autonomy) } \\
\text {-Team work } \\
\text { - Problem-solving } \\
\text { demand } \\
\text { - Job rotation } \\
\text { - Quality management }\end{array}$ & $\begin{array}{l}\text { - Kanban system } \\
\text { - 5S } \\
\text { - Five whys } \\
\text { - Seven wastes } \\
\text { - Kanban } \\
\text { - Kaizen } \\
\text { - Quality circles } \\
\text { - Poka-yoke }\end{array}$ \\
\hline $\begin{array}{l}\text { Womack et } \\
\text { al.(1990, } \\
\text { 2003) }\end{array}$ & $\begin{array}{l}\text { Theoretical and } \\
\text { empirical work } \\
\text { Sample: } 70 \text { firms } \\
\text { in Europe, Japan, } \\
\text { U.S, Australia, } \\
\text { and new entrants } \\
\text { including Korean, } \\
\text { Taiwan, Mexico, } \\
\text { and Brazil }\end{array}$ & $\begin{array}{l}\text { - Define value precisely } \\
\text { from the perspective of } \\
\text { the end customer in terms } \\
\text { of a specific product with } \\
\text { specific capabilities } \\
\text { offered at a specific price } \\
\text { and time. } \\
\text { - Identify the entire value } \\
\text { stream for each product } \\
\text { or product family and } \\
\text { eliminate waste. } \\
\text { - Make the remaining } \\
\text { value-creating steps flow. }\end{array}$ & $\begin{array}{l}\text { - Delegation of tasks and } \\
\text { responsibilities to the } \\
\text { workers } \\
\text {-Team work } \\
\text { - Standardization (i.e. } \\
\text { restrictive procedural } \\
\text { autonomy) } \\
\text { - Problem-solving } \\
\text { demand } \\
\text { - Job rotation } \\
\text { - Quality management }\end{array}$ & $\begin{array}{l}\text { - Five whys } \\
\text { - Kanban } \\
\text { - Kaizen } \\
\text { - Quality circles } \\
\text { - Poka-yoke }\end{array}$ \\
\hline
\end{tabular}




$\begin{array}{ll}\text { Theoretical and } & \text { - Just-in-time (JIT) } \\ \text { empirical work } & \text { - Long term decision } \\ & \text { making } \\ \text { Sample: 1 firm } & \text { - Pull system } \\ \text { (Toyota) } & \text { - Production smoothing } \\ & \text { - Training exceptional } \\ & \text { workers } \\ & \text { - Develop a culture of } \\ & \text { rapid problem solving } \\ & \text { - Respect for } \\ & \text { subcontractors } \\ & \text { - Consensus decision } \\ & \text { making } \\ & \text { - On-site observation of } \\ & \text { problems }\end{array}$

- Design and provide what the customer wants only when the customer wants it.

- Pursue perfection

$\begin{array}{ll}\text { - Standardization of the } & \text { - Poka-yoke } \\ \text { tasks and processes } & \text { - Andon (visual control } \\ \text { - Team work } & \text { device) } \\ \text {-Problem-solving } & \text { - Kaizen }\end{array}$

demand

- Job rotation

- Quality management

Table 3. Application of mixed methods in the context of lean research

\begin{tabular}{|c|c|c|}
\hline Principles $^{7}$ & Decisions & Description \\
\hline 1. Purpose & $\begin{array}{l}\text { Complementarity, } \\
\text { expansion, and } \\
\text { initiation. }\end{array}$ & $\begin{array}{l}\text { This design allowed us to: i) update, in the context of a } \\
\text { specific management situation, how the processes used to } \\
\text { test the different concepts in the quantitative analysis link } \\
\text { together; ii) give a parallel qualitative layer to the statistical } \\
\text { regularities highlighted by the quantitative analysis, with a } \\
\text { view to enriching the understanding of the phenomenon; iii) } \\
\text { to explain the unexpected results yielded by our quantitative } \\
\text { analysis. }\end{array}$ \\
\hline 2. Priority & Equal status & $\begin{array}{l}\text { We gave equal weight to qualitative and quantitative studies. } \\
\text { The quantitative study used data from the 2016-2017 } \\
\text { national French SUMER survey, which includes a sample of } \\
26,494 \text { observations. We conducted a case study to get a } \\
\text { contextual understanding of the phenomenon examined in } \\
\text { focusing on the people's experiences and the meaning they } \\
\text { give to events, processes and their work environment (Gray } \\
\text { et al., 2011; Kiessling and Harvey, 2005). }\end{array}$ \\
\hline
\end{tabular}

3. Implementation and Different fields sample
4. Design and integration of results

We collected quantitative and qualitative data from different fields and analyzed the results obtained from both methodologies.

$(\mathrm{QUAN}+\mathrm{QUAL})$ and qualitative approaches separately, with a view of consolidating the results of these two approaches. 
Table 4. Measure of the dependent and independent variables in 2016-2017 Sumer survey

\section{$\underline{\text { Lean organizational principles }}$}

1. Just-in-time

2. Muda (alleviating waste)

Lean work organization characteristics

3. Job rotation

4. Work standardisation

\section{Quality management}

\section{Team work}

7. Problem-solving demand:

\section{Lean management tools}

\section{Lean tools}

\section{Lean bundle}

\section{Lean bundle}

We selected the following item to measure this variable: "Is there a formalized 'just-in-time' production system?" The answer was coded 1 for "yes" and 0 for "no".

We selected the following item to measure this variable: "Is there a formalized system for reducing waste?" The answer was coded 1 for "yes" and 0 for "no".

We selected the following item to measure this variable: "Do you occupy different work stations?" The answer was coded 1 for "yes" and 0 for "no". We used three items to measure this variable. The first item "In your job, have you had the possibility to change the order of the tasks to be performed?" was coded 0 for "yes" and 1 for "no". The second item "In your job, have you had the possibility to change deadlines" was coded 0 for "yes" and 1 for "no". The third item "In my job, I have no scope to choose the way I carry out my work" was coded 1 for "yes" and 0 for "no". These three items were aggregated in a dummy variable that equals one if there is at least one form of standardization among the three forms. In order to take into account the items in the SUMER survey, we chose to measure the implementation of the quality management system with a "quality index" (Kojima and Kaplinsky, 2004: 201). The variable "ISO standard" was measured by the following dichotomous indicator for the 2016-2017 SUMER survey: "Do you have to follow strict quality process (ISO, EAQF...)." The answer was coded 1 for "yes" and 2 for "no".

We selected the following item to measure this variable: "Is there a formalized system of employee involvement? (e.g. team animation ritual, team board, autonomous team)". The answer was coded 1 for "yes" and 0 for "no".

In accordance with Jackson et al. (1993), we assessed problem-solving demand with the following SUMER item "In your work, have you had the possibility to solve a problem, should one arise?" The answer was coded 1 for "yes" and 0 for "no".

We selected the following item to measure this variable: "Are there lean management tools? (e.g. 5S, five whys, Poka-yoke...)". The answer was coded 1 for "yes" and 0 for "no".

We constructed the dummy variable "lean bundle" and coded 1 when exposed to the combination of all lean organizational principles, work organization 
10. Work intensification

\section{Emplovees' outcomes variables}

\author{
11. Job satisfaction
}

\section{Work health}

\section{General health}

\section{Depression}

\section{Control variables}

\section{Control variables}

characteristics and management tools, and 0 when not exposed to this combination of elements. Work intensification was measured using a four-item scale to tap aspects of work intensification (Jackson and Mullarkey, 2000). The items were answered on a four-point scale: "My job requires me working very fast", "My job requires me working hard", "My job requires me a great deal of work to be done", and "My job requires me doing excessive work". Cronbach's alpha was .79. This variable was treated as a continuous variable.

This variable was measured by the item: "On the whole, I am satisfied with my job". The response scale ranged from 1 (not at all agree) to 4 (totally agree). Although the reliability of a one-item scale is lower than that of a multi-item scale (Peterson, 1994), it is still appropriate (Fisher et al, 2016; Warnous et al, 1997; Kunin, 1955). This variable was treated as an ordinal variable.

This variable was measured by the item: "Do you think your work influences your health?". The possible answers were "Yes, my work is pretty bad for my health" (coded 1), "No, my work does not influence my health" (coded 2), and "Yes, my work is pretty good for my health" (coded 3 ). This variable was treated as an ordinal variable.

This variable was measured by the item: "How is your general health status". The response scale ranged from 1 (very bad) to 5 (very good). This variable was treated as an ordinal variable.

Depression was measured by the Patient Health Questionnaire (PHQ9) developed by Kroenke, Spitzer and Williams (2001). The nine-item scale to assess boundary violations at work used the item stem "In the last 2 weeks, how often have you been embarrassed by the following problems...." and included for example the following items "Little interest or pleasure in doing things" or "Feeling down, depressed, or hopeless". The response scale ranged from 1 (not at all) to 4 (nearly every day). Cronbach's alpha was .85 . This variable was treated as a continuous variable.

The literature suggests that a variety of sociodemographic and organization variables such as sex, age, and occupational status (e.g., fixed term contract, permanent contract, or public sector) may be related to the perceptions of job characteristics and work intensification (Bamberger et al, 2015;

Hackman and Oldham, 1980). The lean literature has emphasized the importance of organization size and unionization status in lean implementation (Shah and Ward, 2003). In order to avoid their potentially confounding effects, we controlled the effects of these variables on employees' outcomes. Sex was treated as a dichotomous variable with men coded as 1 and women coded as 2; age and organization size 
as continuous variables; occupational status as a nominal variable coded 1 for fixed-term contract, 2 for permanent contract, 3 for public sector.

Unionization status was treated as a dichotomous variable coded 1 when the answer to the question "Are there union representatives in your organizations?" was "Yes", and 0 when the answer was "No". 


\section{Table 5. Pearson correlation matrix}

\begin{tabular}{|c|c|c|c|c|c|c|c|c|c|c|c|c|c|c|c|c|c|c|c|c|c|}
\hline & 1 & 2 & 3 & 4 & 5 & 6 & 7 & 8 & 9 & 10 & 11 & 12 & 13 & 14 & 15 & 16 & 17 & 18 & 19 & 20 & 21 \\
\hline 1.Age & 1 & & & & & & & & & & & & & & & & & & & & \\
\hline 2.Sex & $.03 * *$ & 1 & & & & & & & & & & & & & & & & & & & \\
\hline $\begin{array}{l}\text { 3.Organization } \\
\text { size }\end{array}$ & $.07 * *$ & $-.05 * *$ & 1 & & & & & & & & & & & & & & & & & & \\
\hline 4. Unionization & $-.09 * *$ & $.04 * *$ & $-.64 * *$ & 1 & & & & & & & & & & & & & & & & & \\
\hline $\begin{array}{l}\text { 5.Fixed-term } \\
\text { contract }\end{array}$ & $-.1 * *$ & $.03 * *$ & -.01 & $.02 * *$ & 1 & & & & & & & & & & & & & & & & \\
\hline $\begin{array}{l}\text { 6.Permanent } \\
\text { contract }\end{array}$ & .011 & -.00 & $-.3 * *$ & $.22 * *$ & $-.33 * *$ & 1 & & & & & & & & & & & & & & & \\
\hline 7. Public sector & $.100^{* *}$ & $.03 * *$ & $.34 * *$ & $-.26^{* *}$ & $-.13 * *$ & $-.8 * *$ & 1 & & & & & & & & & & & & & & \\
\hline 8. Just-in-time & $.02 * *$ & $.1^{* *}$ & $-.1 * *$ & $.1 * *$ & $.03 * *$ & $-.1 * *$ & $.1 * *$ & 1 & & & & & & & & & & & & & \\
\hline 9. Muda & $-.01 *$ & $.08 * *$ & $-.11 * *$ & $.14 * *$ & $.03 * *$ & $-.1 * *$ & $.09 * *$ & $.33 * *$ & 1 & & & & & & & & & & & & \\
\hline 10. Job rotation & $.07 * *$ & $.03 * *$ & $.09 * *$ & $-.1 * *$ & .005 & -.00 & $.025^{*}$ & $.13 * *$ & $.09^{* *}$ & 1 & & & & & & & & & & & \\
\hline $\begin{array}{l}\text { 11.Work } \\
\text { standardization }\end{array}$ & $.013^{*}$ & -.00 & -.00 & $.04 * *$ & -.00 & .00 & .00 & $.06^{* *}$ & $.03 * *$ & $.05 * *$ & 1 & & & & & & & & & & \\
\hline $\begin{array}{l}\text { 12. Quality } \\
\text { management }\end{array}$ & .00 & $.133^{* *}$ & $-.16^{* *}$ & $.16^{* *}$ & $.04 * *$ & $-.06 * *$ & $.04 * *$ & $.25^{* *}$ & $.27 * *$ & $.12 * *$ & $.06^{* *}$ & 1 & & & & & & & & & \\
\hline $\begin{array}{l}\text { 13.Autonomous } \\
\text { teamwork }\end{array}$ & $.03 * *$ & $.12 * *$ & $-.21 * *$ & $.21^{* *}$ & $.06^{* *}$ & $-.08 * *$ & $.05 * *$ & $.32 * *$ & $.45^{* *}$ & $.037 * *$ & -.00 & $.31 * *$ & 1 & & & & & & & & \\
\hline $\begin{array}{l}\text { 14.Problem- } \\
\text { solving demand }\end{array}$ & $-.1 * *$ & $.1 * *$ & -.00 & -.01 & $.05 * *$ & -.00 & -.00 & .00 & -.00 & -.00 & $-.1 * *$ & .00 & $.03 * *$ & 1 & & & & & & & \\
\hline 15.Lean tools & .005 & $.14^{* *}$ & $-.22 * *$ & $.23^{* *}$ & $.05^{* *}$ & $-.1 * *$ & $.07 * *$ & $.39 * *$ & $.45^{* *}$ & $.06 * *$ & $.03 * *$ & $.45 * *$ & $.57 * *$ & .007 & 1 & & & & & & \\
\hline 16.Lean bundle & .003 & $.045^{* *}$ & $-.06^{* *}$ & $.05^{* *}$ & $.012^{*}$ & $\begin{array}{l}- \\
.040 * *\end{array}$ & $.03^{* *}$ & $.29 * *$ & $.19^{* *}$ & $.13^{* *}$ & $.09 * *$ & $.11 * *$ & $.169^{* *}$ & $.05^{* *}$ & $.17^{* *}$ & 1 & & & & & \\
\hline $\begin{array}{l}\text { 17. Work } \\
\text { intensification }\end{array}$ & -.00 & $.09 * *$ & $.04 * *$ & $-.04 * *$ & $-.03 * *$ & $.021 * *$ & .00 & $-.06^{* *}$ & $-.03^{* *}$ & $-.05 * *$ & $.12 * *$ & $-.08 * *$ & $-.04 * *$ & $-.05 *$ & $-.05^{* *}$ & $-.016^{*}$ & 1 & & & & \\
\hline $\begin{array}{l}\text { 18.General } \\
\text { health }\end{array}$ & $-.18^{* *}$ & $-.09 * *$ & $-.02 * *$ & $.04 * *$ & $.04 * *$ & .00 & $-.04 * *$ & $.02 * *$ & .00 & $.01^{*}$ & $.10^{* *}$ & $.01 *$ & $-.02 * *$ & -.00 & -.00 & .00 & $-.2 * *$ & 1 & & & \\
\hline 19. Work health & $.05 * *$ & $.04 * *$ & $-.02 * *$ & $.029 * *$ & $.02 * *$ & $.01^{*}$ & $-.03^{* *}$ & $.04 * *$ & -.00 & $.04 * *$ & $.11^{* *}$ & $.05 * *$ & -.00 & .00 & .01 & $.016^{*}$ & $\begin{array}{l}- \\
.21^{* *}\end{array}$ & $.22 * *$ & 1 & & \\
\hline $\begin{array}{l}\text { 20.Job } \\
\text { satisfaction }\end{array}$ & $-.03 * *$ & $-.01 *$ & $-.1 * *$ & $.07 * *$ & $.038^{* *}$ & $.01 *$ & $-.04 *$ & $.02 * *$ & $-.02^{* *}$ & .01 & $.14^{* *}$ & $.03 * *$ & -.01 & .00 & .00 & .00 & $.22 * *$ & $.29 * *$ & $.28^{* *}$ & 1 & \\
\hline 21.Depression & $-.05 * *$ & $.15^{* *}$ & $.03 * *$ & $-.03 * *$ & $-.01 *$ & -.00 & $.04 * *$ & $-.03 * *$ & -.00 & $-.03 * *$ & $\begin{array}{l}- \\
.13 * *\end{array}$ & $-.02 * *$ & .01 & $.02 * *$ & .00 & -.00 & $.31^{* *}$ & $\begin{array}{l}- \\
.47 * *\end{array}$ & $\begin{array}{l}- \\
.27 * *\end{array}$ & $\begin{array}{l}- \\
.37 * *\end{array}$ & 1 \\
\hline
\end{tabular}

Notes: Pearson correlation coefficients reported. ${ }^{*} \mathrm{p}<.05$ level, ${ }^{* *} \mathrm{p}<.01$ 
Table 6. Ordered logistic regression (estimated parameters and Wald test) and OLS regression (nonstandardized $\beta$ coefficients and Student test) of the variables pertaining to lean organizational principles, work organization characteristics and management tools on employees' outcomes (2016-2017 SUMER Survey).

\begin{tabular}{|c|c|c|c|c|}
\hline & Job satisfaction ${ }^{1}$ & Work health ${ }^{1}$ & General health $^{1}$ & Depression $^{2}$ \\
\hline $\begin{array}{l}\text { Independent } \\
\text { variable }\end{array}$ & Model 1 & Model 2 & Model 3 & Model 4 \\
\hline \multicolumn{5}{|c|}{ Lean organizational principles } \\
\hline Just-in-time &,$- 061(\mathrm{~ns})$ & $-.210 * * *$ & $-.117 *$ & $.036^{* *}$ \\
\hline Muda & $.175 * * *$ & $.0,86^{*}$ & $.050(\mathrm{~ns})$ & $.015(\mathrm{~ns})$ \\
\hline \multicolumn{5}{|c|}{ Lean work organization characteristics } \\
\hline Job rotation & -.120 &,$- 123 * * *$ & $-.120 * * *$ & $.032 * *$ \\
\hline Work standardization & $-.584 * * *$ & $-.418 * * *$ & $-.363 * * *$ & $.131 * * *$ \\
\hline Quality management & $-.079 *$ & $-.154 * * *$ & $-.081 *$ & $.030 * * *$ \\
\hline Team work & $.120 * * *$ & $.099 *$ & $.043(\mathrm{~ns})$ & $.022(\mathrm{~ns})$ \\
\hline Problem-solving & $-.048(\mathrm{~ns})$ & $-.011(\mathrm{~ns})$ & $-.030(\mathrm{~ns})$ & $-.0,008(\mathrm{~ns})$ \\
\hline \multicolumn{5}{|c|}{ Lean management tools } \\
\hline Lean tools & .008 (ns) & $.073(\mathrm{~ns})$ & $.005(\mathrm{~ns})$ & .000 \\
\hline $\begin{array}{l}\text { Number of } \\
\text { Observations }\end{array}$ & 26494 & 26494 & 26494 & 26494 \\
\hline-2 Log likelihood/ $\mathrm{R}^{2}$ & 26790.57 & 30227.57 & 30885.00 & .18 \\
\hline Chi-square & 565.71 & 435.18 & 909.28 & - \\
\hline d.f & 14 & 14 & 14 & - \\
\hline
\end{tabular}

Notes: $* \mathrm{p}<.05$ level, $* * \mathrm{p}<.01,{ }^{* * *} \mathrm{p}<.001$. Control variables: unionization status, size of the organization, age, sex, occupational status. ${ }^{1}$ : ordered logistic regression. ${ }^{2}$ : OLS regression

Table 7. Ordered logistic regression (estimated parameters and Wald test) and OLS regression (nonstandardized $\beta$ coefficients and Student test) of the variables pertaining to lean bundle on employees' outcomes (2016-2017 SUMER Survey)

\begin{tabular}{|c|c|c|c|c|c|c|}
\hline & $\begin{array}{c}\text { Job } \\
\text { satisfaction }^{1}\end{array}$ & $\begin{array}{c}\text { Work } \\
\text { health }^{1}\end{array}$ & $\begin{array}{c}\text { Work } \\
\text { health }^{1}\end{array}$ & $\begin{array}{c}\text { General } \\
\text { health}^{1}\end{array}$ & $\begin{array}{c}\text { General } \\
\text { health }^{1}\end{array}$ & Depression $^{2}$ \\
\hline $\begin{array}{l}\text { Independent } \\
\text { variable }\end{array}$ & Model 5 & Model $6 a$ & Model $6 b$ & Model $7 a$ & Model $7 b$ & Model 8 \\
\hline Lean bundle & $-.115(\mathrm{~ns})$ & $-.276^{*}$ & -.199 (ns) & $-.302 * *$ & $-.259 *$ & $.036(\mathrm{~ns})$ \\
\hline $\begin{array}{l}\text { Work } \\
\text { intensification }\end{array}$ & - & - & $-.712 * * *$ & - & $-.614 * * *$ & - \\
\hline $\begin{array}{l}\text { Number of } \\
\text { Observations }\end{array}$ & 26494 & 26494 & 26494 & 26494 & 26494 & 26494 \\
\hline $\begin{array}{l}-2 \text { Log } \\
\text { likelihood/R }\end{array}$ & 10979.45 & 10845.38 & 28801.84 & 12582.86 & 30429.94 & .11 \\
\hline Chi-square & 236.51 & 203.17 & 1368.81 & 1041.17 & 1826.06 & - \\
\hline d.f & 7 & 7 & 8 & 7 & 8 & - \\
\hline
\end{tabular}

Notes: ${ }^{*} \mathrm{p}<.05$ level, ${ }^{* *} \mathrm{p}<.01,{ }^{* * *} \mathrm{p}<.001$, ns: non-significant. Control variables: unionization status, size of the organization, age, sex, occupational status. ${ }^{1}$ : ordered logistic regression. ${ }^{2}$ : OLS regression 
Table 8. OLS regression (non-standardized $\beta$ coefficients and Student test) of the variables pertaining to lean bundle on work intensification (2016-2017 SUMER Survey)

\section{Work intensification}

\begin{tabular}{lc}
\hline Independent variable & Model 9 \\
Lean bundle & $.075^{*}$ \\
Number of Observations & 37179 \\
$\mathrm{R}^{2}$ & .11 \\
\hline
\end{tabular}

Notes: ${ }^{*} \mathrm{p}<.05$ level, ${ }^{* *} \mathrm{p}<.01,{ }^{* * *} \mathrm{p}<.001$. Control variables: unionization status, size of the organization, age, sex, occupational status.

\section{Table 9. Sample characteristics}

\begin{tabular}{lll}
\hline Initial of each Employee & Age & Tenure \\
\hline Employee A & 29 & 8 \\
Employee B & 28 & 7 \\
Employee C & 43 & 17 \\
Employee D & 44 & 11 \\
Employee E & 54 & 33 \\
Employee F & 53 & 34 \\
\hline
\end{tabular}

\section{Appendix 1}

\section{Interview protocol}

\section{Socio-professional trajectory}

Gender, age, seniority, status (permanent contract, permanent contract, temporary work), current job Professional experience and degrees (studies, experiences and professional projects)

Family characteristics

2. Working time/working hours

What are your working hours?

Have they changed? Since when?

3. Organization and working conditions

Could you describe your work?

Can you describe your working conditions (noise, heat, painful postures...)?

4. Relationships in the workplace (manager, supervisor, colleagues)

What are your relationships at work with your colleagues or your supervisor (or your hierarchy)?

5. Job satisfaction

Are you satisfied with your work?

\section{Occupational Health}

Do you relate your work to your health? Are you stressed or tired? Do you have muscle problems or tendons (e.g. wrist)? 


\section{Appendix 2}

Template outline: lean organizational principles, work organization characteristics and management tools, and employees' job satisfaction and health

1. Lean management

i. Lean organizational principles
i. Just-in-time
ii. $\quad$ Production smoothing
iii. Shortening setup time
iv. Alleviating waste (Muda)
v. Improvement activities

ii. Lean work organization characteristics

i. Job rotation

ii. Team work

iii. Quality management

iv. Problem-solving demand

v. Decentralization of responsibilities

vi. Predictability

vii. Work intensification

viii. Work density

iii. Lean management tools
i. U-turn layout
ii. Kanban
iii. Kaizen
iv. Andon
v. Quality circles
vi. Poka-yoke

2. Well-being

i. Health at work

i. Work-related musculoskeletal disorders (WMSDs).

ii. Sickness absenteeism

iii. Stress

ii. Job satisfaction

iii. Mutual aid and cooperation

\section{Appendix 3}

Template scheme and sample quotes, observation notes, data or phrases from internal documentation

Sample quotes, observation notes, data or phrases from internal documentation

\section{A. Aggregate theme: Lean} management
A.1 Lean organizational principles
A.1.1 Just-in-time

The system implemented is based on a customer-supplier logic which consists in delivering the product to the customer in just-intime (observation note) 
A.1.2 Production smoothing

A.1.3 Alleviating waste

A.1.4 Improvement activities

A.2 Lean work organization characteristics

A.2.1 Job rotation
"We wanted to improve smooth flow" (consultant interview)

Buffer stocks were removed (observation note)

Employees' ideas for improving the production system were encouraged by top management (observation note)

"Top management had promised to implement job rotation, but we can't see it" (Trade Union interview)

A.2.2 Team work

A.2.3 Quality management

A.2.4 Problem-solving demand

A.2.5 Decentralization of responsibilities

A.2.6 Predictability

A.2.7 Work intensification

A.2.8 Work density
Team work was not implemented (observation note)

Quality standards (ISO 9001 standards) and self-monitoring of work quality have been applied (observation note)

'In technical engineering, there's no one there when there's a problem. So, we solve the problem by ourselves" (employee interview)

"Since they have a production to hold, when it's not done, they always worry about having to justify it. They are always asked to justify why they couldn't make a part" (line manager interview)

"We don't know what kind of part we're going to get. Before, we weren't working with just-in-time, but now we're really moving towards it" (employee interview)

"We have to rush; they're always asking more and more from us" (employee interview)

"On the production sheet (...), there is a short heading called 'observations' where we can write down all the problems we encounter daily. For example, on the test beds (the test bed is used to test the reliability of the repaired piece), when you have a programming problem, or you're missing the right tools... And then it's our boss who goes through it" (employee interview) 
A.3 Lean management tools

A.3.1 U-turn layout

A.3.2 Kanban

A.3.3 Kaizen

B.1.1 Work-related musculoskeletal disorders (WMSDs).

B.1.2 Sickness absenteeism

B.1.3 Stress

B.2 Job satisfaction

B.3 Mutual aid and cooperation
Work stations are arranged in a Ushaped production (observation note)

"The Kanban system was implemented to improve the smooth flow between work stations" (consultant interview)

A continued improvement of the production system through employee suggestions (observation note)

"I've informed the Health and Safety Committee about WMSD problems that appeared in the sectors" (Occupational health physician interview)

Sickness absenteeism increased by $82 \%$ between 2006 and 2008 after the implementation of lean (data from social annual reports)

"I'm not even sure that lowering the rates would solve the WMSD problem... If we haven't solved the problem in the guys' heads, stress at work, atmosphere at work, I say, we won't solve the WMSD problem. Even if we lower the work pace, the guys will always have trouble ... We see guys who catch badly on soft work positions... It's not possible, it can't be just the gesture. There's something else in their heads that happens, so it hurts!" (Trade Union interview)

"We are highly skilled employees and we do low-skilled jobs. I'm afraid of losing my skills" (employee interview)

"Compared to the degree I have, I'm not pleased with my work" (employee interview)

We have noticed mutual aid and cooperation between employees. For example, a box containing sweets was brought by younger employees for everyone (observation note) 